\title{
Subaqueous speleothems (Hells Bells) formed by the interplay of pelagic redoxcline biogeochemistry and specific hydraulic conditions in the El Zapote sinkhole, Yucatán Peninsula, Mexico
}

\author{
Simon Michael Ritter ${ }^{1}$, Margot Isenbeck-Schröter ${ }^{1,2}$, Christian Scholz $^{1}$, Frank Keppler ${ }^{1,2}$, Johannes Gescher ${ }^{3,4}$, \\ Lukas Klose $^{1}$, Nils Schorndorf ${ }^{1}$, Jerónimo Avilés Olguín ${ }^{5}$, Arturo González-González ${ }^{6}$, and Wolfgang Stinnesbeck ${ }^{1,2}$ \\ ${ }^{1}$ Institute of Earth Sciences, Heidelberg University, Im Neuenheimer Feld 234-236, 69120 Heidelberg, Germany \\ ${ }^{2}$ Heidelberg Center for the Environment (HCE), Heidelberg University, 69120 Heidelberg, Germany \\ ${ }^{3}$ Institute for Applied Biosciences, Department of Applied Biology, Karlsruhe Institute of \\ Technology (KIT), Karlsruhe, Germany \\ ${ }^{4}$ Institute for Biological Interfaces, Karlsruhe Institute of Technology (KIT), Eggenstein-Leopoldshafen, Germany \\ ${ }^{5}$ Instituto de la Prehistoria de América, Carretera federal 307, km 282, Solidaridad, 77711 Solidaridad, Quintana Roo, Mexico \\ ${ }^{6}$ Museo del Desierto, Carlos Abedrop Davila 3745, Nuevo Centro Metropolitano de Saltillo, 25022 Saltillo, Coahuila, Mexico
}

Correspondence: Simon Michael Ritter (simon.ritter@geow.uni-heidelberg.de)

Received: 20 December 2018 - Discussion started: 24 January 2019

Revised: 29 April 2019 - Accepted: 7 May 2019 - Published: 4 June 2019

\begin{abstract}
Unique bell-shaped underwater speleothems were recently reported from the deep $(\sim 55 \mathrm{~m})$ meromictic El Zapote sinkhole (cenote) on the Yucatán Peninsula, Mexico. The local diving community has termed these speleothems as Hells Bells because of their shape and appearance in a dark environment in $\sim 28-38 \mathrm{~m}$ water depth above a sulfidic halocline. It was also suggested that Hells Bells form under water, yet the mystery of their formation remained unresolved. Therefore, we conducted detailed hydrogeochemical and geochemical analyses of the water column and Hells Bells speleothems including stable carbon isotopes. Based on the comprehensive results presented in this study we deduce that both biogeochemical processes in the pelagic redoxcline and a dynamic halocline elevation of El Zapote cenote are essential for Hells Bells formation. Hells Bells most likely form in the redoxcline, a narrow 1-2 m thick water layer immediately above the halocline where a pelagic chemolithoautotrophic microbial community thrives from the upward diffusion of reduced carbon, nitrogen and sulfur species released from organic matter degradation in organic-rich debris. We hypothesize that chemolithoautotrophy, in particular proton-consuming nitrate-driven anaerobic sulfide oxidation, favors calcite precipitation in the redoxcline and hence Hells Bells formation. A dynamic elevation of the halocline as a hydraulic response to droughts, annual tidal variability
\end{abstract}

and recharge events is further discussed, which might explain the shape of Hells Bells as well as their occurrence over a range of $10 \mathrm{~m}$ water depth. Finally, we infer that highly stagnant conditions, i.e., a thick halocline, a low-light environment and sufficient input of organic material into a deep meromictic cenote are apparent prerequisites for Hells Bells formation. This might explain their exclusivity to only a few cenotes in a restricted area of the northeastern Yucatán Peninsula.

\section{Introduction}

Speleothems, such as stalactites or dripstones, result from physicochemical processes under subaerial conditions in a cave atmosphere. Calcite usually precipitates due to $\mathrm{CO}_{2}$ degassing and evaporation of water enriched in dissolved carbonate dripping into the cave. In recent years, however, researchers have identified a small group of speleothems that appear to have calcified underwater. For these formations, interactions between physicochemical and biological calcite precipitation processes are interpreted (Barton and Northup, 2007; Bontognali et al., 2016; Gradzinski et al., 2012; Guido et al., 2013; Holmes et al., 2001; Jones et al., 2008, 2012; Macalady et al., 2007; Macintyre, 1984; Me- 


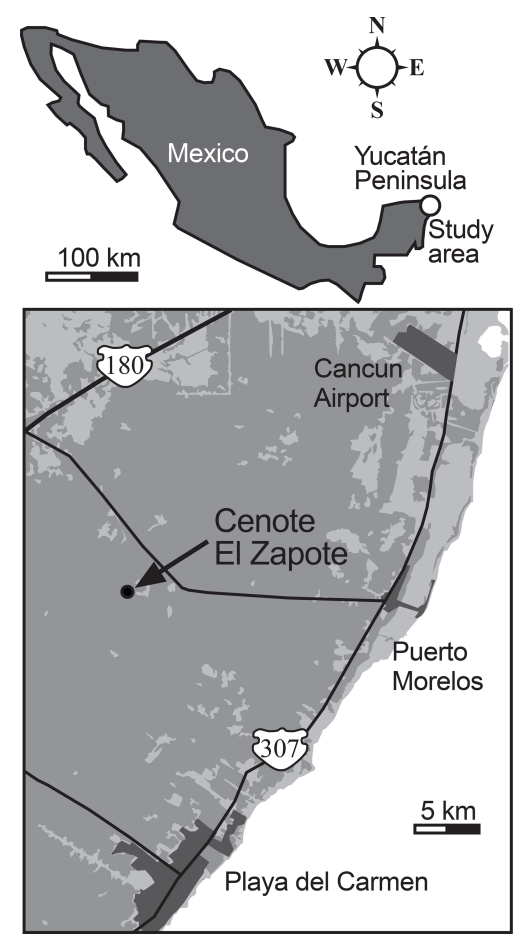

Figure 1. Location of the studied El Zapote cenote with respect to Mexico and the Yucatán Peninsula.

lim et al., 2001; Queen and Melim, 2006; Tredici et al., 2018). We recently presented a spectacular example for these subaqueous speleothems termed Hells Bells from El Zapote sinkhole about $26 \mathrm{~km}$ west of Puerto Morelos on the Yucatán Peninsula of southern Mexico (Fig. 1) (Stinnesbeck et al., 2017b).

These bell-shaped structures consist of calcite and reach lengths of up to $2 \mathrm{~m}$. Hells Bells conically expand downward with strictly horizontal ring-like concentric swellings and neckings on the surface (Fig. 2). Apparently, they form in a lightless environment in freshwater above the anoxic and sulfidic halocline (Stinnesbeck et al., 2017b). Because of these environmental conditions which include complete darkness, the local diving community has termed the El Zapote speleothem formations as Hells Bells. They grow from the cavern ceiling and wall. Additionally, small individuals also cover a tree that has fallen into the sinkhole around $\sim 3.5 \mathrm{ka}$ cal BP, which indicates that Hells Bells must have formed during the Holocene and thus at periods when the deep sections of the cenote had already been submerged for thousands of years (Stinnesbeck et al., 2017b). Thus, the conditions for the formation of the biggest underwater speleothems worldwide must have existed consistently throughout the past thousands of years at El Zapote cenote.

The internal structure of Hells Bells is characterized by laminar fabrics of alternating units of elongated dogtooth spar calcite and microcrystalline spar calcite. Microspar layers and corroded lobes of dogtooth spar crystals indicate ei- ther discontinuous growth of Hells Bells and/or intermittent dissolution. Phylogenetic analyses of Hells Bells speleothem surfaces from specimens of 33 and $34 \mathrm{~m}$ water depths indicate that microorganisms inhabiting the Hells Bells potentially support a full nitrogen cycle and autotrophic growth (Stinnesbeck et al., 2017b). The growth of Hells Bells may thus be mediated by specific physical and biogeochemical conditions above and in the halocline, while formation of Hells Bells was likely restricted to the lowermost part of the freshwater body. However, due to the limited available data including geochemical parameters, the suggested processes for Hells Bells formation were regarded as highly speculative.

Therefore, in this study we conducted detailed geochemical analysis including stable carbon isotopes of the water body and Hells Bells speleothems of El Zapote cenote. Based on the results, we present a hypothesis on the subaqueous growth of these exceptional structures. We deduce that both biogeochemical processes in the pelagic redoxcline and a dynamic halocline elevation of El Zapote cenote are essential for Hells Bells formation.

\subsection{Geological background}

The northeastern Yucatán Peninsula (YP) consists of horizontally layered shallow-water carbonates of Miocene, Pliocene and Pleistocene ages (Lefticariu et al., 2006; Weidie, 1985) and probably hosts the largest network of underwater caves in the world. The Mexican state of Quintana Roo alone counts more than 370 underwater caves with a confirmed total length of $\sim 1460 \mathrm{~km}$ and individual cave systems reaching up to $>350 \mathrm{~km}$ in length (QRSS, 2018). These cave systems developed predominantly by the interaction of glacioeustasy, littoral processes and mixing-zone hydrology during glacial periods of the Pleistocene (Smart et al., 2006; Weidie, 1985). Precipitation rapidly infiltrates through the porous limestone into the underlying coastal aquifer consisting of a meteoric water mass, the freshwater lens above a saline water mass intruding from the coast (e.g., Kovacs et al., 2017a). The thickness of the freshwater lens varies between $\sim 10$ and $100 \mathrm{~m}$ and is generally thinner towards the coast (Beddows et al., 2002), while seawater intrudes up to $100 \mathrm{~km}$ inland (Beddows et al., 2007). The halocline separates the meteoric and marine water bodies and is usually characterized by undersaturation with respect to $\mathrm{CaCO}_{3}$, leading to cave formation and conduit enlargement in the coastal carbonate aquifer (Back et al., 1986; Gulley et al., 2016; Mylroie and Carew, 1990; Smart et al., 2006). The depth of the halocline increases with distance from the coast (Bauer-Gottwein et al., 2011); areas closer to the coast show a higher salinity of the freshwater lens than inland areas (Kovacs et al., 2017b). The position of the halocline is also dependent on global sea level and the thickness of the freshwater lens. Hydraulic gradients are generally very low with values of $1-10 \mathrm{~cm} \mathrm{~km}^{-1}$ (Bauer-Gottwein et al., 2011, and ref- 

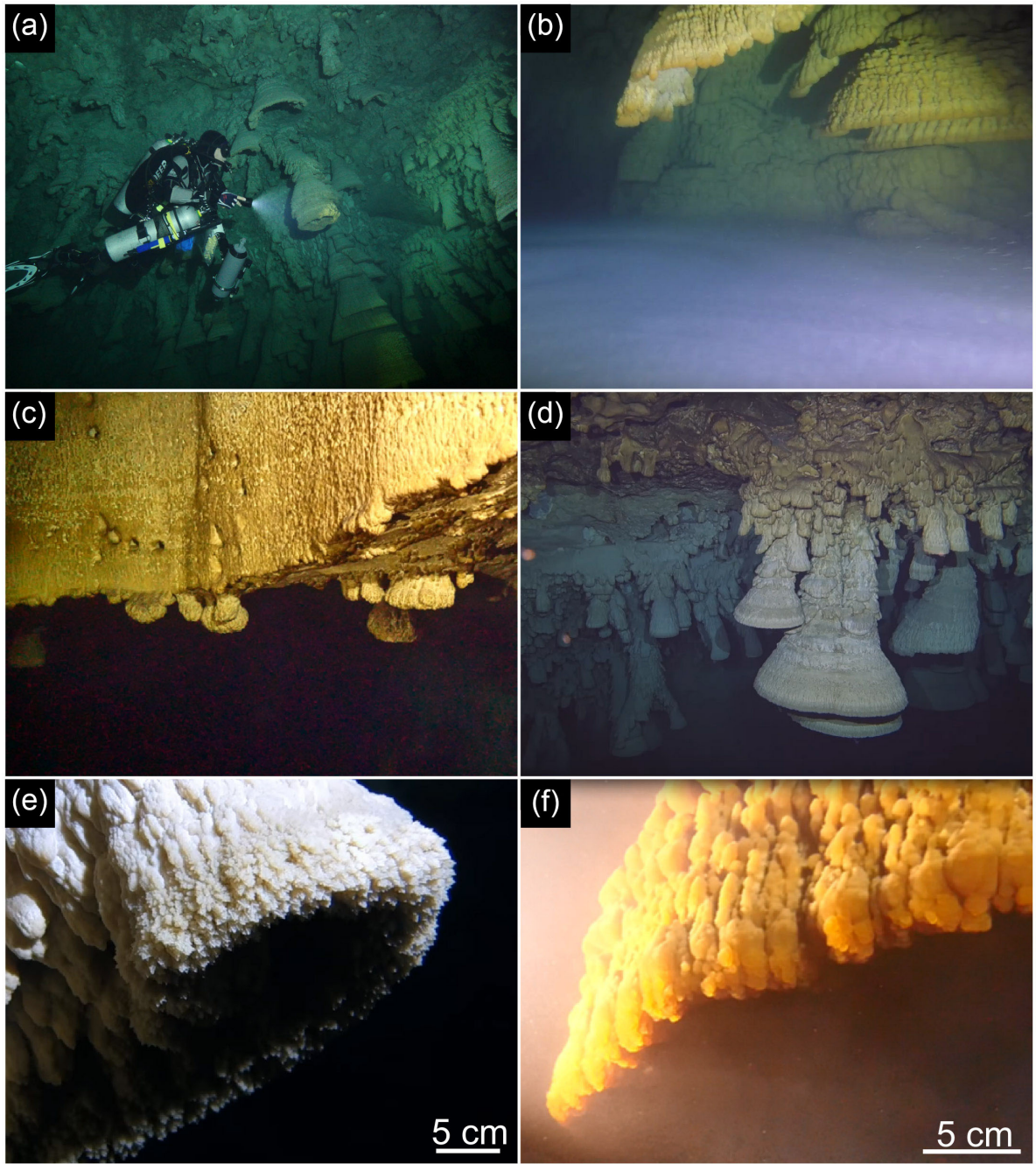

Figure 2. Technical diver in El Zapote cenote during a sample-collecting dive carrying the Niskin bottle, sample containers and the multiparameter sonde attached to the sidemount gas bottle (a). Turbid layer immediately above the halocline forming a distinct horizontal white cloud at around $36 \mathrm{~m}$ water depth (b). Transition of cenote shaft to the open dome-shaped cavern at $28 \mathrm{~m}$ water depth (c), where the vertical wall of the cenote shaft is devoid of Hells Bells speleothems (upper part of c), whereas small specimens of Hells Bells grow down from the horizontal ceiling below (lower part of c). Brown-colored manganese oxide coatings on host rock carbonates and Hells Bells speleothems reach down from $28 \mathrm{~m}$ water depth to around $30 \mathrm{~m}$ water depth at the transition of the cenote shaft to the wide dome-like cavern (c, d). Below around $30 \mathrm{~m}$ water depth, Hells Bells speleothem and host rock carbonate surfaces are devoid of brownish manganese oxide coatings. They are white to light-gray colored revealing a distinct horizontal boundary (d). Close-up shot of the lowermost calcite rim of a Hells Bells speleothem at around 32-35 m water depth showing millimeter-sized calcite crystals (e).

erences therein). Although Moore et al. (1992) and Stoessell et al. (1993) report that the thickness of the freshwater lens does not vary significantly between seasons or on a yearly basis, local and short-termed variations are possible and were reported by Escolero et al. (2007), who documented a significant halocline elevation of up to $17.5 \mathrm{~m}$ between two measurements in the years 2000 and 2003.

Sinkholes (locally called cenotes) were formed by dissolution and collapse of the carbonate rock. They are common throughout the YP, connecting the subterranean cave system with the surface (Bauer-Gottwein et al., 2011). For more detailed information about the formation and occurrence of cenotes on the YP we refer the readers to Torres-Talamente et al. (2011) and Schmitter-Soto et al. (2002).

\subsection{El Zapote cenote}

El Zapote cenote is located $26 \mathrm{~km}$ west of Puerto Morelos on the YP of southeast Mexico $\left(20^{\circ} 51^{\prime} 27.78^{\prime \prime} \mathrm{N}\right.$, $87^{\circ} 07^{\prime} 35.93^{\prime \prime} \mathrm{W}$; Fig. 1). In cross-section the cenote is bottle-shaped with a deep vertical water-filled shaft that opens at $28 \mathrm{~m}$ water depth to a wide cavern of 60 to $100 \mathrm{~m}$ in diameter that reaches to about $54 \mathrm{~m}$ water depth with a $20 \mathrm{~m}$ 
high debris mound in the center (Fig. 3a). A fallen tree stands on top of the debris mound and small Hells Bells cover the stem. There are no apparent passages or conduits that connect El Zapote cenote to a cave system. Additional details on El Zapote cenote are given in Stinnesbeck et al. (2017b) and in Stinnesbeck et al. (2017a), who described the new genus and species of a giant ground sloth, Xibalbaonyx oviceps, from an individual that was found on the floor of El Zapote cenote.

\section{Methods}

\subsection{Sampling}

Sampling at El Zapote cenote was carried out between 10 and 15 December 2017. Water samples were taken early in the morning prior to any tourist diving group activities to ensure sampling of an undisturbed water column. Water sample recovery and the recording of the in situ parameters were carried out with a winch from the surface down to the top of the debris mound $(0-36 \mathrm{~m})$ and by technical divers from the top of the debris mound down to the cenote floor following the slope of the debris mound (Fig. 2a).

In situ parameters $\mathrm{pH}( \pm 0.1)$, eH $( \pm 20 \mathrm{mV})$, dissolved oxygen $\left( \pm 0.1 \mathrm{mg} \mathrm{L}^{-1}\right.$, detection limit $\left.0.2 \mathrm{mg} \mathrm{L}^{-1}\right)$, electrical conductivity $( \pm 0.05 \%$ of value $)$, temperature $\left( \pm 0.01^{\circ} \mathrm{C}\right)$ and turbidity ( $\pm 2 \%$ of value) were determined with a multiparameter water sonde EXO1 (Xylem Analytics, Norway). All parameters, including water depth via pressure measurement $( \pm 0.04 \mathrm{~m})$, were internally logged by the sonde. Water depths were corrected to the ambient air pressure of the respective day of sampling. In order to reach the greatest possible water depth, a total of four winch-operated profiles were run within $2 \mathrm{~d}$, with laterally shifting starting points of the profile at the surface. In order to complete the measurement in the whole water column, technical divers carried the EXO1 probe with them during sampling. Due to increasing sulfide concentrations in water depths below the turbid layer and interaction of sulfide with the $\mathrm{Ag} / \mathrm{AgCl} \mathrm{pH}$ electrode, a shift of $\mathrm{pH}$ of up to $0.2 \mathrm{pH}$ units towards higher values was observed when comparing the $\mathrm{pH} \operatorname{logs}$ of the way down with the $\mathrm{pH}$ logs of the way up (Fig. S1). This shift is dependent on the exposure time of the electrode and the respective sulfide concentrations and could neither be quantified nor corrected for. However, the sensor recovers to initial $\mathrm{pH}$ values after a certain time in non-sulfide water. Therefore, the $\mathrm{pH}$ values presented in this study are representative for the water column from 0 to $37 \mathrm{~m}$ water depth and are overestimated in water depths from 37 to $50 \mathrm{~m}$ where the actual absolute $\mathrm{pH}$ values are most likely lower, i.e., more acidic. Repeated measurements with a new sonde of the same type in June 2018 confirmed this assumption and showed lower $\mathrm{pH}$ values below $37 \mathrm{~m}$ water depth (Fig. S2).
Water samples from 15 to $35 \mathrm{~m}$ water depth were retrieved using a winch and a $5 \mathrm{~L}$ polyethylene Niskin bottle (HYDRO-BIOS, Kiel, Germany). Sampling depths represent the center of the $0.6 \mathrm{~m}$ tall sampling bottle and were determined by cable length with a depth counter attached to the winch. Water samples from 35.2 to $45 \mathrm{~m}$ water depth were retrieved by technical divers (Fig. 2a). Water samples collected by the technical divers were taken with $120 \mathrm{~mL}$ polyethylene (PE) containers. The containers were carried open and water-filled by the divers. At the desired sample depth, the water in the containers was exchanged with surrounding water via shaky motions, sealed underwater and the water depth was noted for each sample. Water samples for the analysis of dissolved gases $\left(\mathrm{CO}_{2}, \mathrm{CH}_{4}\right)$ were taken in $24 \mathrm{~mL}$ glass vials and sealed underwater at the respective depth (four samples at each depth level). The EXO1 sonde was attached to a side mounted compressed air bottle pointing towards the front of the technical diver in order to record the in situ parameters of each water sample (Fig. 2a). The depth of the water samples taken by technical divers was corrected to the depth of the attached logging device (EXO1). For four samples between 35 and $37 \mathrm{~m}$, depth was interpreted from the increase of sodium and chloride contents correlated to the electrical conductivity in this interval.

Water samples were treated on-site immediately after the water samples were retrieved. Samples for determination of dissolved ions were taken with $20 \mathrm{~mL}$ sterile polypropylene syringes and then filtered through a cellulose acetate filter $(0.45 \mu \mathrm{m})$. Samples for cation determination were acidified with $50 \mu \mathrm{L}$ of $65 \% \mathrm{HNO}_{3}$ analytical grade (A.G.) to adjust a $\mathrm{pH}<2$; they were stored in $15 \mathrm{~mL}$ Falcon polypropylene centrifuge tubes. Samples for anion determination were taken following the same procedure, but not acidified, and stored cool in $15 \mathrm{~mL}$ Falcon polypropylene centrifuge tubes. Samples for the determination of dissolved inorganic carbon (DIC) and dissolved organic carbon (DOC) were filtered through a cellulose acetate filter $(0.45 \mu \mathrm{m})$, stored in $24 \mathrm{~mL}$ glass vials and sealed gas-tight. Samples for the determination of content and isotopic ratios of the dissolved gases $\mathrm{CH}_{4}$ and $\mathrm{CO}_{2}$ were filled in $24 \mathrm{~mL}$ glass vials; subsequently $100 \mu \mathrm{L} 60 \% \mathrm{HgCl}_{2}$ solution was added via a syringe pierced through the septum to sterilize the samples.

A large volume sample $(5 \mathrm{~L})$ of the turbid layer water at around $36 \mathrm{~m}$ water depth was taken with a Niskin bottle by technical divers and subsequently filtered through a $0.45 \mu \mathrm{m}$ cellulose acetate filter with a vacuum pump. The filter was air-dried, and back in the laboratory a small piece of the filter was coated with carbon for subsequent secondary electron (SE) imaging and analyses.

Sulfide and nitrite were determined on-site by photometric analysis with a photometer (Hach Lange DR200) using Merck Spectroquant ${ }^{\circledR}$ spectrometric methods.

Technical divers collected several Hells Bells samples grown on the tree trunk from seven water depth levels between 32.7 and $37.3 \mathrm{~m}$. To obtain the youngest part of indi- 

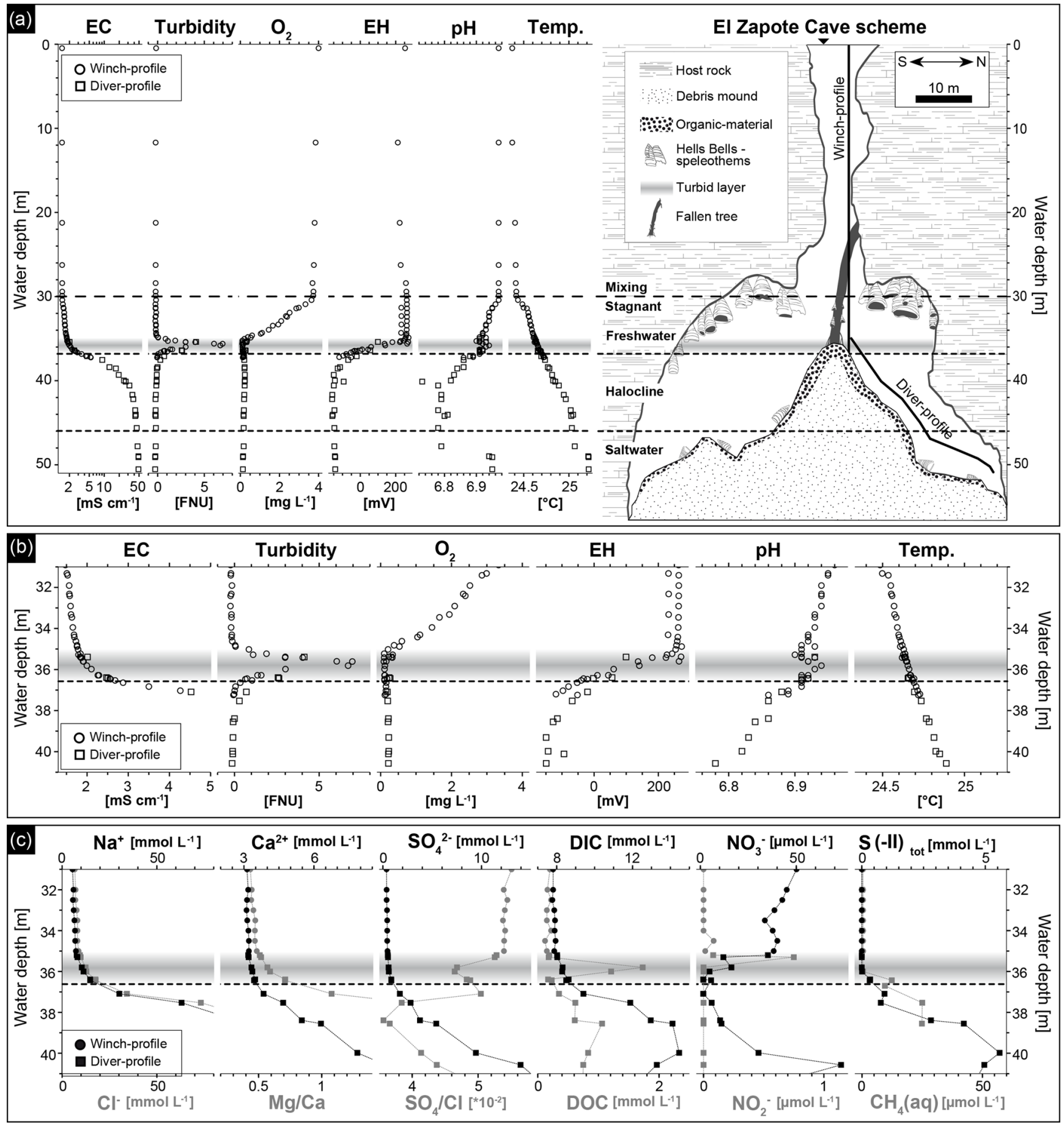

Figure 3. Hydrogeochemistry of the water column of El Zapote cenote. The horizontal gray band indicates the depth position of the turbid layer, while the dashed line indicates the top of the halocline at $36.6 \mathrm{~m}$ water depth. (a) Water in situ parameters versus water depth (left) in relation to the El Zapote cenote cross section (right). In situ parameters and samples were taken along a winch profile and a diver profile as shown in the cenote cross section. Note the logarithmic scale of the electrical conductivity (EC). (b) Close-up of the water in situ parameters at 31-41 m water depth. Note that the scale of EC is non-logarithmic and is only shown for the range between 1 and $5 \mathrm{mS} \mathrm{cm}{ }^{-1}$, in order to point out the increase in salinity at the beginning of the halocline. (c) Water chemical parameters determined in the water column between 31 and $41 \mathrm{~m}$ water depth. $\mathrm{Na}^{+}$and $\mathrm{Cl}^{-}$concentrations are only shown in the range of $0-80 \mathrm{mmol} \mathrm{L}^{-1}$ to highlight the concentration pattern above and within the halocline. 
vidual Hells Bells growth, samples were first studied under the microscope. Only samples with apparently fresh, wellaccentuated crystal tips were chosen for geochemical and stable isotope analysis.

\subsection{Analytical measurements}

\subsubsection{Major and trace element analysis}

Major cation concentrations (Ca, $\mathrm{Mg}, \mathrm{Sr}, \mathrm{Ba}, \mathrm{K}, \mathrm{Na}, \mathrm{Si}$ ) of water samples were determined by optical emission spectroscopy with an Agilent 720 ICP-OES. Quality control was performed using the reference materials SPS-SW1, SPSSW2 and TMDA-70.2. Recovery rates were in the range of $97 \%-104 \%$ for the analyzed elements. Measurement precision for each element was $<2 \%$ (RSD, $n=3$ ).

Concentrations of anions $\mathrm{Cl}^{-}, \mathrm{SO}_{4}^{2-}$ and $\mathrm{NO}_{3}^{-}$were determined with ion chromatography (Dionex ICS-1100) with an RSD of $<3 \%$ derived from long-term repeated analysis of reference material SPS-NUTR-WW1. The concentrations of DOC were determined with a Total Carbon Analyzer (Shimadzu TOC-CPH) with an RSD of $<2 \%$ derived from repeated analysis of an in-house standard water.

Orthophosphate was determined by the photometric molybdenum phenyl blue method on $880 \mathrm{~nm}$ light extinction with a UV-VIS photometer (SPECORD ${ }^{\circledR} 50$, Analytik Jena).

Trace element concentrations ( $\mathrm{Fe}, \mathrm{Mn}, \mathrm{Mo}, \mathrm{P}, \mathrm{S}, \mathrm{U}$ ) of selected water samples were determined by high resolution inductively coupled plasma mass spectrometry (HR-ICP-MS) (Thermo Finnigan ${ }^{\mathrm{TM}}$ Element $2^{\mathrm{TM}}$ ). Analyses were normalized by an internal indium standard. Calibration solutions were prepared with the MERCK multi-element standard VI solution. The recovery rates of SLRS5 reference material were $95 \%(\mathrm{Fe}), 93 \%(\mathrm{Mn}), 82 \%(\mathrm{Mo})$ and $133 \%(\mathrm{U})$ with respect to the referenced values, and $\mathrm{P}$ and $\mathrm{S}$ were within the range of reported uncertified values. The precision was $<3.7 \%$ (RSD) derived from repeated $(n=5)$ measurements of the reference material in the measurement run.

Around $3 \mathrm{mg}$ of the powdered speleothem samples was digested in $2 \mathrm{~mL} 10 \% \mathrm{HNO}_{3}$ for major and trace cation analyses. Subsequently, concentrations of $\mathrm{Ca}, \mathrm{Mg}, \mathrm{Sr}, \mathrm{Ba}, \mathrm{P}, \mathrm{S}, \mathrm{Fe}$ and $\mathrm{Mn}$ of the aliquots were determined by ICP-OES. Quality control of the measurement was performed using reference materials SPS-SW1 and SPS-SW2 with recovery rates ranging from $99 \%$ to $111 \%$ for the analyzed elements. Quality control for digestion of the carbonate material was performed with limestone reference material ECRM 752-1 with recovery rates between $106 \%$ and $110 \%$ for the elements $\mathrm{Ca}, \mathrm{Mg}, \mathrm{Ba}, \mathrm{Sr}$ and $\mathrm{Mn}$, and $82 \%$ for the element $\mathrm{Fe}$.

Calcite saturation and $\mathrm{HS}^{-}$activity was calculated with PHREEQC (Parkhurst and Appelo, 1999) using phreeqc.dat. The diffusion $J$ was calculated with the first Fick's law with diffusion coefficients of $D_{\mathrm{O}_{2}}, D_{\mathrm{NO}_{3}^{-}}, D_{\mathrm{HCO}_{3}^{-}}$and $D_{\mathrm{HS}^{-}}$of 2.1, 1.9, 1.2 and $1.8 \times 10^{-9} \mathrm{~m}^{-2} \mathrm{~s}^{-1}$, respectively taken from phreeqc.dat (Parkhurst and Appelo, 1999).

\subsubsection{Stable carbon isotope and concentration measurements of $\mathrm{CH}_{4}$ and $\mathrm{CO}_{2}$}

For the determination of dissolved gases, a $5 \mathrm{~mL}$ headspace with nitrogen gas ( $\left.\mathrm{N}_{2} 99.999 \%\right)$ was created in each of the four samples of the respective water depth. Samples were taken for the analysis of dissolved gases at ambient laboratory temperatures of $23^{\circ} \mathrm{C}$. After equilibration $(\sim 24 \mathrm{~h})$, the headspaces of the four samples were transferred and combined in one $12 \mathrm{~mL}$ evacuated exetainer vial. To ensure a pressureless transfer of the gas phase from the headspace to the exetainer, a brine solution of $200 \mathrm{~g} \mathrm{~L}^{-1} \mathrm{NaCl}$ was introduced at the bottom of the vial and the gas phase was simultaneously removed and subsequently transferred to evacuated exetainer vials. Concentrations of $\mathrm{CH}_{4}$ and $\mathrm{CO}_{2}$ in the gas samples were measured as follows: headspace samples $(50 \mu \mathrm{L})$ were injected in a flow of $1 \mathrm{~mL} \mathrm{~min}^{-1}$ of helium with a split ratio of $5: 1$ to a ShinCarbon ST column (80/100 mesh, $2 \mathrm{~m} \times 0.53 \mathrm{~mm}$ i.d., Restek Corporation) quantified by a gas chromatograph (GC-2010 Plus, Shimadzu Corporation, Kyoto, Japan) coupled to a barrier ionization discharge (BID) detector (BID-2010 Plus, Shimadzu Corporation, Kyoto, Japan). The GC oven was initially held at $30^{\circ} \mathrm{C}$ for $1 \mathrm{~min}$ and then ramped at $10^{\circ} \mathrm{C} \mathrm{min}^{-1}$ up to $200^{\circ} \mathrm{C}$. Quantification of $\mathrm{CH}_{4}$ and $\mathrm{CO}_{2}$ was carried out by comparison of the integrals of the peaks eluting at the same retention time as that of the authentic standard with calibration curves. The dissolved concentrations of $\mathrm{CH}_{4}$ in the water were then calculated from the measured mixing ratio using Henry's law (Wiesenburg and Guinasso, 1979) and solubility coefficients for $\mathrm{CH}_{4}$ according to Weiss (1974) and Yamamoto et al. (1976).

Stable carbon isotope ratios of $\mathrm{CO}_{2}\left(\delta^{13} \mathrm{C}-\mathrm{CO}_{2}\right.$ values $)$ were analyzed by gas chromatography stable isotope ratio mass spectrometry (GC-IRMS) by an HP $6890 \mathrm{~N}$ gas chromatograph, coupled to a 253 Plus $^{\text {TM }}$ isotope ratio mass spectrometer (ThermoQuest Finnigan, Bremen, Germany) with average analytical uncertainties of $0.2 \%$ for $\delta^{13} \mathrm{C}^{-} \mathrm{CO}_{2}$ values. $2 \sigma$ uncertainties were derived from five replicates. All ${ }^{13} \mathrm{C} /{ }^{12} \mathrm{C}$ isotope ratios are expressed in the conventional $\delta$ notation in per mill versus VPDB, defined in Eq. (1):

$\delta^{13} \mathrm{C}_{\text {VPDB }}=\left[\left({ }^{13} \mathrm{C} /{ }^{12} \mathrm{C}_{\text {sample }}\right) /\left({ }^{13} \mathrm{C} /{ }^{12} \mathrm{C}_{\text {standard }}\right)\right]-1$.

For details of the $\delta^{13} \mathrm{C}-\mathrm{CO}_{2}$ measurements by GC-IRMS we would like to refer to previous studies by Keppler et al. (2010) and Laukenmann et al. (2010).

Stable carbon isotope ratios of $\mathrm{CH}_{4}\left(\delta^{13} \mathrm{C}_{-} \mathrm{CH}_{4}\right.$ values $)$ were determined by GC-IRMS. In brief, $\mathrm{CH}_{4}$ of the sample was trapped on HayeSep ${ }^{\circledR} \mathrm{D}$ and then transferred to the IRMS system (ThermoFinnigan Delta ${ }^{\text {plus }}$ XL, Thermo Finnigan, Bremen, Germany). The working reference gas was carbon dioxide of high purity (carbon dioxide 4.5, Messer Griesheim, Frankfurt, Germany) with a known $\delta^{13} \mathrm{C}$ $\mathrm{CH}_{4}$ value of $-23.634 \%$ o $\pm 0.006 \%$ versus Vienna Peedee 
Belemnite (VPDB). All $\delta^{13} \mathrm{C}_{-} \mathrm{CH}_{4}$ values were corrected using two $\mathrm{CH}_{4}$ working standards (Isometric Instruments, Victoria, Canada) and normalized by two-scale anchor calibration according to Paul et al. (2007). The average standard deviation of the analytical measurements was in the range of $0.1 \%$ o to $0.3 \%$.

The $\delta^{13} \mathrm{C}_{-} \mathrm{HCO}_{3}^{-}$values were calculated from the measured $\delta^{13} \mathrm{C}-\mathrm{CO}_{2}$ of the headspace of the water samples that was generated in the laboratory as equilibrium fractionation at $23{ }^{\circ} \mathrm{C}\left(\delta^{13} \mathrm{C}^{-\mathrm{CO}_{2}}+8.16 \%=\delta^{13} \mathrm{C}-\mathrm{HCO}_{3}^{-}\right)$after Mook (2000).

For stable carbon isotope analyses of carbonates, approximately $50 \mu \mathrm{g}$ of powdered speleothem subsamples was analyzed using a ThermoFinnigan ${ }^{\mathrm{TM}}$ MAT253 Plus ${ }^{\mathrm{TM}}$ gas source mass spectrometer equipped with a Thermo Fisher Scientific ${ }^{\mathrm{TM}}$ Kiel IV carbonate device at Heidelberg University. Values are reported relative to VPDB (Eq. 1) through the analysis of an in-house standard (Solnhofen limestone) calibrated to IAEA-603. The precision of the $\delta^{13} \mathrm{C}_{\text {calcite }}$ analyses is better than $0.08 \%$ and $0.06 \%$ (at $1 \sigma$ level), respectively.

\subsubsection{Optical methods}

Hells Bells specimen ZPT 7, described in Stinnesbeck et al. (2017b), was vertically cut in half and thin sections were prepared from one half of the specimen. Photographs of the thin sections were taken with a KEYENCE VHX-6000.

Polished counterparts of the thin sections and small pieces of Hells Bells were coated with carbon for secondary electron (SE) imaging and energy dispersive X-ray (EDX) analyses. SE imaging and element mapping were performed with a Leo 440 at $20 \mathrm{kV}$ with an X-Max $80 \mathrm{~mm}^{2}$ detector.

\section{Results}

\subsection{Hydrogeochemistry}

The water column of the El Zapote cenote is stratified into an oxygenated freshwater body overlying an anoxic transition zone of increasing electrical conductivity (EC), the halocline, and an anoxic saltwater body below (Fig. 3a). Water temperatures vary little between 0 to $30 \mathrm{~m}$ water depth (24.37$24.42^{\circ} \mathrm{C}$ ); a steep increase is identified in a narrow zone from 30 to $32 \mathrm{~m}$ water depth $\left(24.42-24.55^{\circ} \mathrm{C}\right)$, followed by almost invariable temperatures from $32 \mathrm{~m}$ water depth $\left(24.55^{\circ} \mathrm{C}\right)$ down to the bottom of the cenote $\left(25.22^{\circ} \mathrm{C}\right)$ (Fig. 3a and b). A distinct density boundary, the top of the halocline, is identified at $36.6 \mathrm{~m}$ water depth by a steep increase in EC. Seawater-like salinity is reached at around $46 \mathrm{~m}$ water depth indicating a thick halocline layer of around $10 \mathrm{~m}$ in thickness (Fig. 3a and b). Low turbidity readings indicate clear water throughout the water column, except for a $\sim 1.6 \mathrm{~m}$ thick layer of increased turbidity immediately above the halocline from 35.0 to $36.6 \mathrm{~m}$ water depth, with a peak of 8.0 Formazin Nephelometric Units (FNUs) detected at $35.8 \mathrm{~m}$ water depth
(Fig. 3a and b; Table S1). This turbid layer is also easily detected macroscopically in the water column as a white cloudy layer (Fig. 2b) and coincides with a distinct redoxcline from $\sim 35$ to $37 \mathrm{~m}$ water depth, in which the redox potential (EH) decreases from $\sim 250$ to $\sim-140 \mathrm{mV}$ (Fig. 3a and b). Dissolved oxygen (DO) decreases nearly linear from $30 \mathrm{~m}$ to concentrations below detection limit at $\sim 35 \mathrm{~m}$ water depth just above the turbid layer. Below, DO is below detection limit (Fig. $3 \mathrm{a}$ and $\mathrm{b}$ ). The $\mathrm{pH}$ shows neutral values from 0 to $30 \mathrm{~m}$ water depth and slightly decreases to 6.90 at the top of the turbid layer (Fig. 3a). Within the turbid layer pH values increase to more alkaline values of around 6.94 at $35.8 \mathrm{~m}$ water depth. The $\mathrm{pH}$ values decrease again below the turbid layer to 6.73 at $40 \mathrm{~m}$ and invariably remain at about this value down to $48 \mathrm{~m}$. From there, values increase to about neutral (6.95) close to the cenote bottom at $49 \mathrm{~m}$ water depth (Fig. 3a and b).

Concentrations of the major dissolved ions $\mathrm{Na}^{+}, \mathrm{Cl}^{-}$, $\mathrm{Ca}^{2+}, \mathrm{Mg}^{2+}$ and $\mathrm{SO}_{4}^{2-}$ reflect the stratification of the water column in the cenote, with generally low concentrations in the freshwater body from 0 to $30 \mathrm{~m}$ water depth and slightly increasing concentrations from $30 \mathrm{~m}$ water depth to the top of the turbid layer at $35 \mathrm{~m}$ water depth, a stronger increase within the turbid layer from 35 to $36.6 \mathrm{~m}$ water depth, and an even strong increase from the top of the halocline at $36.6 \mathrm{~m}$ water depth down to the cenote bottom (Fig. 3c and Table S2). $\mathrm{Mg} / \mathrm{Ca}$ ratios strongly increase from the top of the turbid layer at $35 \mathrm{~m}$ water downwards, due to higher $\mathrm{Mg}$ concentrations in the saltwater body (Fig. 3c). Although sulfate concentrations increase downwards from the top of the halocline, a relative decrease of $\mathrm{SO}_{4}^{2-}$ ions is detected, compared to the chemically conservative ion $\mathrm{Cl}^{-}$, by a decrease in $\mathrm{SO}_{4}^{2-} / \mathrm{Cl}^{-}$within the turbid layer and below in the halocline (Fig. 3c).

Concentrations of DIC are about $7.8 \mathrm{mmol} \mathrm{L}^{-1}$ in the freshwater body. They increase in the turbid layer and show a peak at $40 \mathrm{~m}$ water depth with concentrations increasing to $14.5 \mathrm{mmol} \mathrm{L}^{-1}$; below, they decrease towards the cenote bottom (Fig. 3c and Table S2). The dissolved organic carbon (DOC) concentrations are low in the freshwater body and show a distinct peak within the turbid layer, coinciding with the peak in turbidity at $35.7 \mathrm{~m}$ water depth (Fig. 3c). Below the turbid layer DOC concentrations slightly increase and peak at $39-40 \mathrm{~m}$ water depth, decreasing from there towards the cenote bottom (Fig. 3c and Table S2). Nitrate concentrations are $\sim 50 \mu \mathrm{mol} \mathrm{L}^{-1}$ in the freshwater unit of the cenote shaft (Table S2). They decrease from $30 \mathrm{~m}$ water depth towards the top of the turbid layer and rapidly fall below detectable concentrations within this layer (Fig. 3c). Nitrite peaks in a narrow zone at the top of the turbid layer with concentrations of up to $0.8 \mu \mathrm{mol} \mathrm{L}{ }^{-1}$ (Fig. 3c). High total sulfide (S(-II)) concentrations of up to $5.6 \mathrm{mmol} \mathrm{L}^{-1}$ were detected in $40 \mathrm{~m}$ water depth. Concentrations decrease upwards, fading in the lower part of the turbid layer at $36 \mathrm{~m}$ water depth (Fig. 3c). Below the $40 \mathrm{~m}$ depth level, S(-II) concentrations 
decrease to values around $3 \mathrm{mmol} \mathrm{L}^{-1}$ down to $45 \mathrm{~m}$ water depth (Fig. 3c and Table S2). Concentrations of dissolved $\mathrm{CH}_{4}\left(\mathrm{CH}_{4}(\mathrm{aq})\right)$ are low in the freshwater body with values of about $0.09 \mu \mathrm{mol} \mathrm{L}^{-1}$. Methane concentrations increase from the turbid layer at $36 \mathrm{~m}$ water depth downwards to values of $25 \mathrm{mmol} \mathrm{L}^{-1}$ at $39 \mathrm{~m}$ water depth (Fig. 3c).

\subsubsection{Calcite saturation}

The calculated saturation index (SI) of calcite shows calcite saturation in the freshwater body and the uppermost part of the halocline with values from 0.03 to 0.07 (Fig. S2). The SI closely follows the $\mathrm{pH}$ in the freshwater body revealing a distinct peak of slightly higher values of $\mathrm{SI}=0.1$ in the turbid layer at $\sim 36 \mathrm{~m}$ water depth. The water body below the redoxcline is undersaturated with respect to calcite, indicating calcite dissolution in the halocline (Fig. S2).

\subsubsection{Trace elements}

Dissolved iron and manganese concentrations are very low in the freshwater body with concentrations of 0.1 and $0.01 \mu \mathrm{mol} \mathrm{L}{ }^{-1}$, respectively, and slightly increase within the turbid layer towards the saltwater body, to concentrations of up to $0.47(\mathrm{Fe})$ and $0.06(\mathrm{Mn}) \mu \mathrm{mol} \mathrm{L}{ }^{-1}$ (Fig. S3). Phosphate and silica concentrations are invariably low in the freshwater body $\left(\mathrm{P}_{\text {ortho }} \sim 0.25\right.$ and $\mathrm{Si} \sim 63 \mu \mathrm{mol} \mathrm{L}^{-1}$ ) and increase in the saltwater body peaking at $40 \mathrm{~m}$ water depth with concentrations up to $10.3\left(\mathrm{P}_{\text {ortho }}\right.$ ) and $275(\mathrm{Si}) \mu \mathrm{mol} \mathrm{L}^{-1}$ (Fig. S3). Uranium content correlates to the redox potential of the water as indicated by uniform contents of $\sim 0.012 \mu \mathrm{mol} \mathrm{L}^{-1}$ in the freshwater column and rapidly decreasing values of 1 order of magnitude in the turbid layer, to $0.0012 \mu \mathrm{mol} \mathrm{L}^{-1}$ at $40 \mathrm{~m}$ water depth (Fig. 4 and Table S2).

\subsubsection{Stable carbon isotopes of DIC and $\mathrm{CH}_{4}$}

The $\delta^{13} \mathrm{C}-\mathrm{HCO}_{3}^{-}$values at water depths from 28 to $42 \mathrm{~m}$ are shown in Fig. 4. The average $\delta^{13} \mathrm{C}-\mathrm{HCO}_{3}^{-}$value is $-9.8 \%$ in the freshwater body where DIC content is about $8 \mathrm{mmol} \mathrm{L}^{-1}$. In the turbid layer, $\delta^{13} \mathrm{C}-\mathrm{HCO}_{3}^{-}$values show a distinct peak towards less negative values of up to $-7.9 \%$ at slightly increasing DIC concentrations. Below the turbid layer, $\delta^{13} \mathrm{C}$ $\mathrm{HCO}_{3}^{-}$values rapidly decrease towards more negative values of $-12.4 \%$ o between 39 and $42 \mathrm{~m}$ water depth at increasing DIC concentrations (Fig. 4). A rather slight increase in $\delta^{13} \mathrm{C}$ $\mathrm{HCO}_{3}^{-}$values $(-11.6 \% \circ \pm 0.7 \%$ ) is observed towards the cenote bottom at $44 \mathrm{~m}$ water depth (Table S3).

The $\delta^{13} \mathrm{C}-\mathrm{CH}_{4}$ values are shown alongside with the $\mathrm{CH}_{4}$ concentrations in Fig. 5. The pattern of $\delta^{13} \mathrm{C}-\mathrm{CH}_{4}$ within the water column is similar to that of $\delta^{13} \mathrm{C}-\mathrm{HCO}_{3}^{-}$. In the freshwater body, values of $\delta^{13} \mathrm{C}-\mathrm{CH}_{4}$ are approximately constant at about $-49 \%$ and $\mathrm{CH}_{4}$ concentrations are very low, roughly corresponding to that of atmospheric equilibrium $\left(0.04-0.09 \mu \mathrm{mol} \mathrm{L}{ }^{-1}\right)$. The $\delta^{13} \mathrm{C}-\mathrm{CH}_{4}$ values increase to $-28 \%$ within the turbid layer and again decrease to

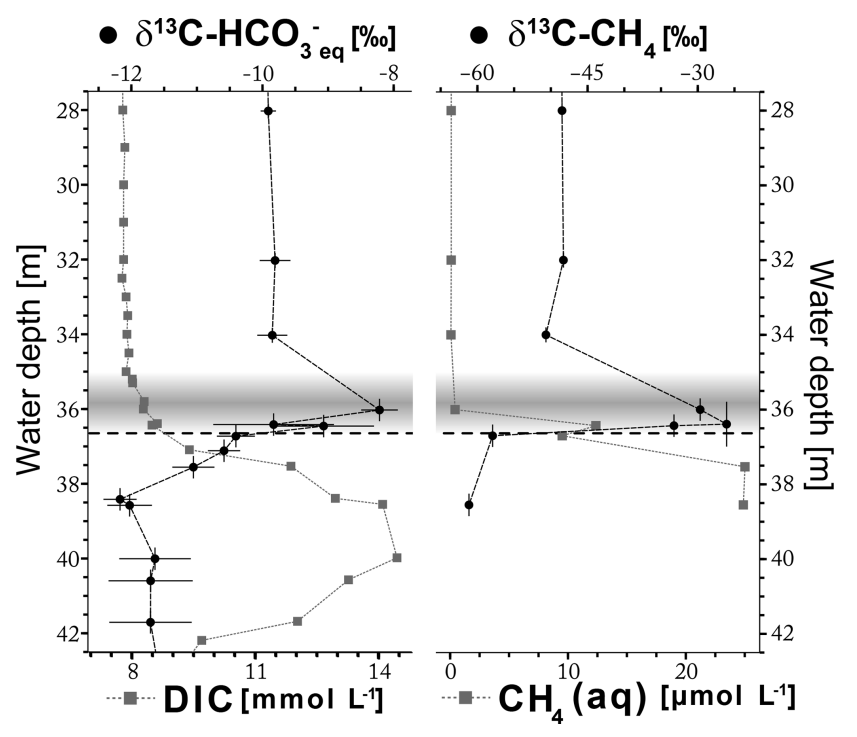

Figure 4. Stable carbon isotope values $\delta^{13} \mathrm{C}-\mathrm{HCO}_{3}^{-}$eq of the dissolved $\mathrm{HCO}_{3}^{-}$in equilibrium with $\delta^{13} \mathrm{C}-\mathrm{CO}_{2}$ values measured in headspace and $\delta^{13} \mathrm{C}_{-} \mathrm{CH}_{4}$ values of water samples alongside the concentrations of DIC and $\mathrm{CH}_{4}$ of water samples. The gray band represents the turbid layer in 35-36.6 m water depth, and the horizontal dashed line indicates the top of the halocline at $36.6 \mathrm{~m}$ water depth. Horizontal error bars represent $2 \sigma$ uncertainties, and vertical error bars indicate up to $0.6 \mathrm{~m}$ uncertainty of gas samples that were not taken from the sample used to determine chemical parameters (see Sect. 2.1).

$-61 \%$ o below the turbid layer, while $\mathrm{CH}_{4}$ concentrations increase within and below the turbid layer (Fig. 4).

\subsection{Petrography of Hells Bells speleothems}

Petrographic characteristics of Hells Bells are shown in Fig. 6. The size of individual crystals of Hells Bells is varying from micrometer scale to several millimeter-sized crystals that are easily identified macroscopically. The latter are frequently dominant in the youngest calcite rims at the bottom of Hells Bells at water depths reaching from $\sim 28$ to $\sim 35 \mathrm{~m}$ (Fig. 2e). Hells Bells at greater water depths show rounded or globular calcite surfaces at the lowermost margin of the speleothems indicating dissolution (Fig. 2f). Scanning electron microscope (SEM) images of the lowermost part of Hells Bells surfaces are shown in Fig. 6a, b and c. The calcite morphology varies from bladed or book-like calcite crystals (Fig. 5a), dogtooth-like calcite crystals (Fig. 5b) and blocky calcite rhombs (Fig. 5c). In thin sections of the specimen ZPT-7 (Fig. 5d1) (see also Stinnesbeck et al., 2017b), these crystal morphologies are expressed as rather botryoidal (dogtooth-like and blade-shaped) and as mosaic calcite phases (blocky calcite rhombs) (Fig. S5). Electron images of the polished counter pieces of the thin section are shown in Fig. 5d2. An element map of $\mathrm{Mg}$ shows that botryoidal 

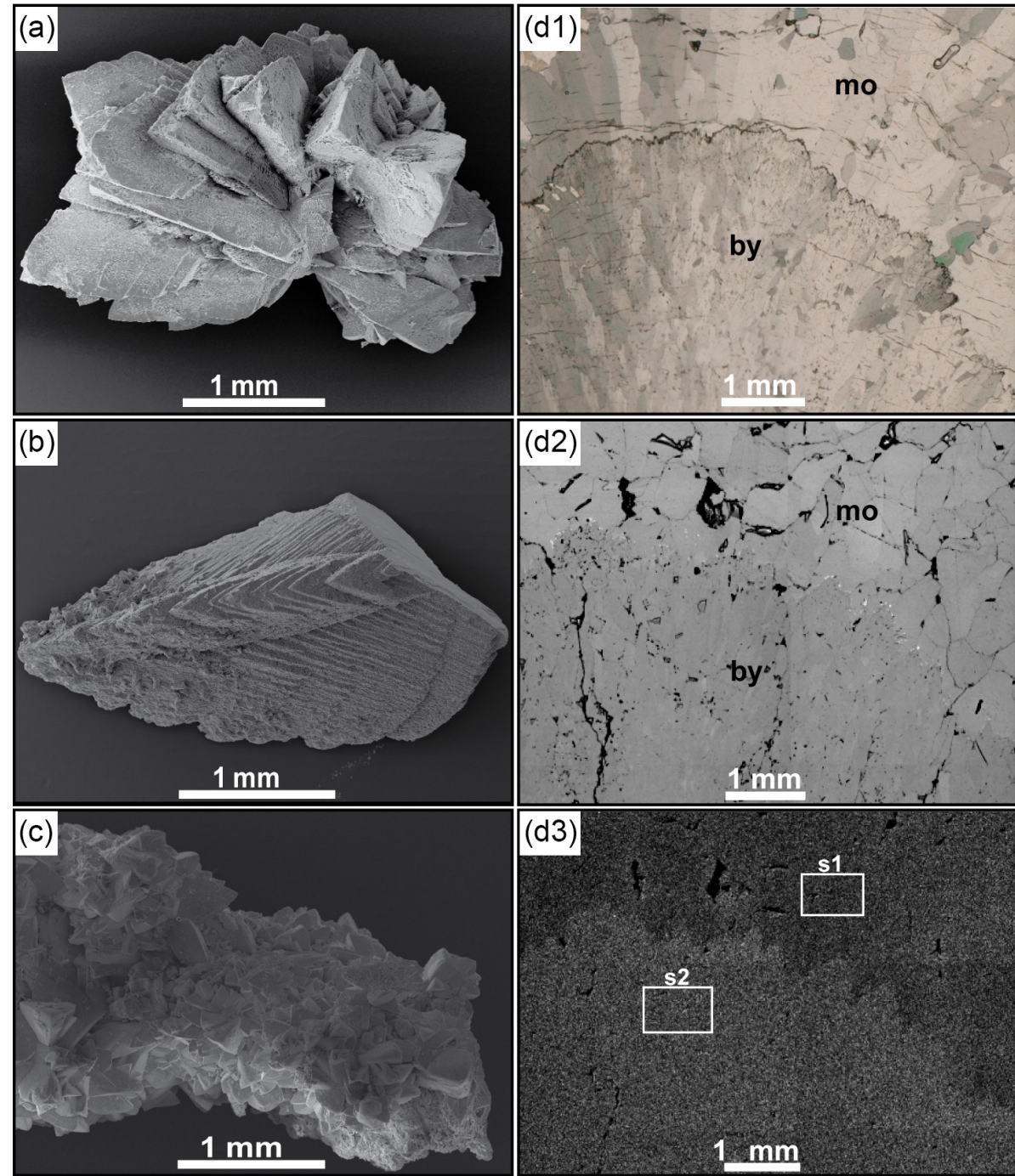

Figure 5. Petrographic characteristics of Hells Bells speleothems. SEM images of Hells Bells samples Z17-8DC (a), Z17-18J (b) and Z179J (c) of El Zapote cenote showing bladed (a), dogtooth-like (b) and blocky calcite rhombs (c). Polarized transmitted light-microscopic images of a thin section from ZPT-7 (d1) (shown in Stinnesbeck et al., 2017b) showing different calcite fabrics of angular coarse-grained mosaic calcite (mo) and fine-grained elongated botryoidal calcite (by). The same detail is shown in the BSE image of the polished counter slab that corresponds to the thin section (d2). The Mg element map (d3), where higher abundances of $\mathrm{Mg}$ appear brighter, indicates a difference in $\mathrm{Mg}$ content between the botryoidal and mosaic calcite phases. The white rectangles represent areas of measured integrated element spectra.

calcite phases incorporated more $\mathrm{Mg}$ (appearing brighter in Fig. 5d3) than the mosaic calcite phases (appearing darker in Fig. 5d3).

\subsection{Geochemistry of Hells Bells speleothems}

Samples were collected from the lowermost and presumably youngest part of several Hells Bells specimens that grew on a ceiba tree fallen into the El Zapote cenote at about $3.5 \mathrm{ka}$ cal BP (Stinnesbeck et al., 2017b). They were analyzed for major and trace elements and stable carbon isotopes. The results are given in Table 1 .

\subsubsection{Major and trace elements}

The calcite of Hells Bells speleothems revealed no residues after digesting $\sim 3 \mathrm{mg}$ sample in $12 \mathrm{~mL}$ dilute $1 \mathrm{M}$ nitric acid indicating that Hells Bells calcite is devoid of acid insoluble impurities. The $\mathrm{Mg} / \mathrm{Ca}, \mathrm{Sr} / \mathrm{Ca}$ and $\mathrm{Ba} / \mathrm{Ca}$ molar ratios show narrow ranges with mean values of $22.5 \pm 2.9 \times 10^{-3}$, $38.6 \pm 5.9 \times 10^{-5}$ and $1.10 \pm 0.31 \times 10^{-5}$, respectively. They are closely related and positively correlate in each sample (Fig. 6a). There is also a trend towards decreasing ratios with increasing water depth of the respective sample (Fig. 6b). Iron and manganese show more variable concentrations with molar ratios of $\mathrm{Fe} / \mathrm{Ca}$ and $\mathrm{Mn} / \mathrm{Ca}$ between 3.0 and 


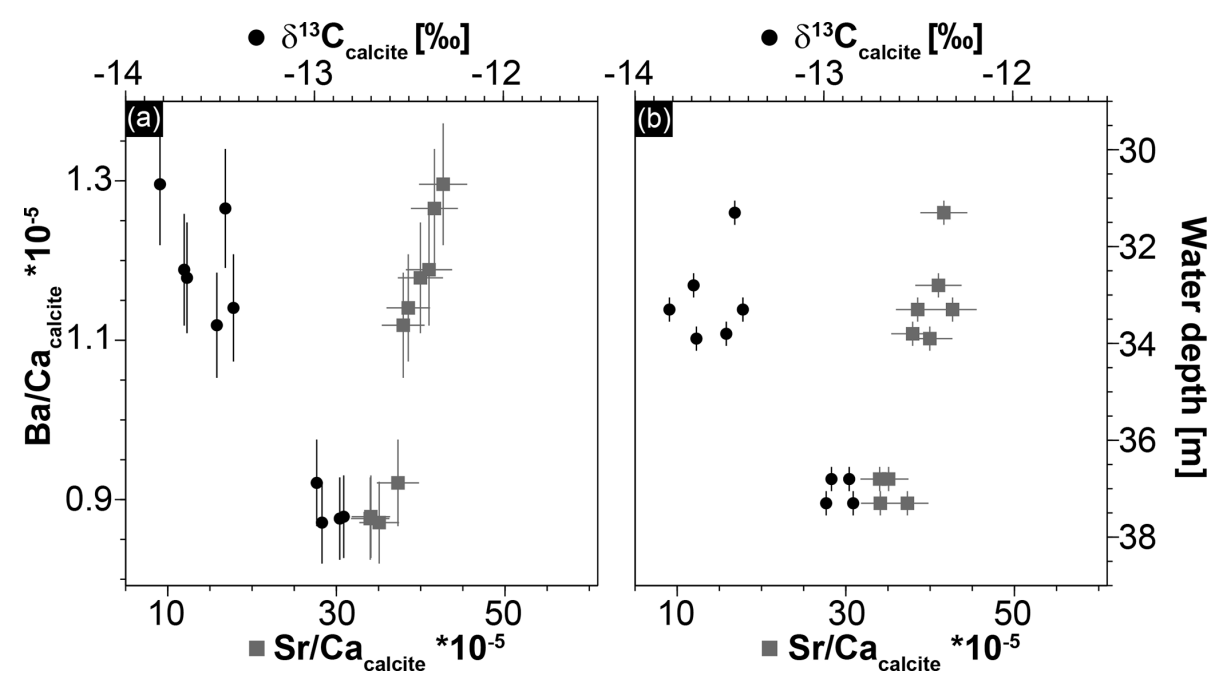

Figure 6. Geochemical data of Hells Bells speleothems showing a strong correlation between $\mathrm{Sr} / \mathrm{Ca}$ and $\mathrm{Ba} / \mathrm{Ca}$ ratios $\left(r^{2}=0.91\right)$ and between $\mathrm{Ba} / \mathrm{Ca}$ and $\delta^{13} \mathrm{C}_{\text {calcite }}\left(r^{2}=0.89\right)$ (a) and a trend of increasing $\delta^{13} \mathrm{C}_{\text {calcite }}$ and decreasing $\mathrm{Sr} / \mathrm{Ca}$ with increasing water depth of the samples (b). Given uncertainties represent $2 \sigma$ standard deviations and $\pm 0.25 \mathrm{~m}$ is assumed as uncertainty for the water depth of the Hells Bells samples.

Table 1. Geochemistry of samples from the lowermost tips of Hells Bells growing on a subfossil ceiba tree that fell into the El Zapote cenote about 3500 cal BP. Individual tree bells were sampled at water depths from 31.3 to $37.3 \mathrm{~m}$. The lack of samples in water depths from 34.3 to $36.8 \mathrm{~m}$ water depth is due to poor visibility in the turbid layer above the halocline (compare Fig. 1b). Given uncertainties represent $2 \sigma$ standard deviations.

\begin{tabular}{|c|c|c|c|c|c|c|c|c|}
\hline $\begin{array}{l}\text { Sample } \\
\text { no. }\end{array}$ & $\begin{array}{r}\text { Water } \\
\text { depth }(m)\end{array}$ & $\begin{array}{r}\mathrm{Mg} / \mathrm{Ca} \\
\left(\times 10^{-3}\right)\end{array}$ & $\begin{array}{r}\mathrm{Sr} / \mathrm{Ca} \\
\left(\times 10^{-5}\right)\end{array}$ & $\begin{array}{r}\mathrm{Ba} / \mathrm{Ca} \\
\left(\times 10^{-5}\right)\end{array}$ & $\begin{array}{r}\mathrm{Fe} / \mathrm{Ca} \\
\left(\times 10^{-5}\right)\end{array}$ & $\begin{array}{r}\mathrm{Mn} / \mathrm{Ca} \\
\left(\times 10^{-6}\right)\end{array}$ & $\begin{array}{r}\mathrm{S} / \mathrm{Ca} \\
\left(\times 10^{-3}\right)\end{array}$ & $\begin{array}{r}\delta^{13} \mathrm{C}_{\text {calcite }} \\
(\% \text { ovPDB })\end{array}$ \\
\hline 1 & 31.3 & & & & & & & \\
\hline 2 & 31.3 & 21.4 & 41.6 & 1.27 & 4.3 & 21 & 2.78 & $-13.47 \pm 0.01$ \\
\hline 3 & 32.8 & 25.6 & 41.0 & 1.19 & 5.2 & 26 & 2.69 & $-13.69 \pm 0.01$ \\
\hline 4 & 32.8 & & & & & & & \\
\hline 5 & 33.3 & 22.0 & 42.7 & 1.30 & 3.8 & 24 & 3.05 & $-13.82 \pm 0.01$ \\
\hline 6 & 33.3 & 22.3 & 38.5 & 1.14 & 3.0 & 16 & 2.54 & $-13.43 \pm 0.01$ \\
\hline 7 & 33.8 & & & & & & & \\
\hline 8 & 33.8 & 20.8 & 37.9 & 1.12 & 3.5 & 24 & 2.72 & $-13.52 \pm 0.01$ \\
\hline 9 & 33.9 & 23.2 & 40.0 & 1.18 & 3.9 & 22 & 2.76 & $-13.68 \pm 0.01$ \\
\hline 10 & 33.9 & & & & & & & \\
\hline 11 & 36.8 & 22.3 & 34.0 & 0.88 & 11.3 & 39 & 3.14 & $-12.87 \pm 0.02$ \\
\hline 12 & 36.8 & 21.1 & 34.1 & 0.88 & 10.6 & 28 & 3.02 & $-12.85 \pm 0.00$ \\
\hline 13 & 37.3 & 24.0 & 37.3 & 0.92 & 6.2 & 32 & 3.17 & $-12.99 \pm 0.01$ \\
\hline \multirow[t]{3}{*}{14} & 37.3 & & & & & & & \\
\hline & Mean & 22.5 & 38.6 & 1.10 & 5.76 & 25.8 & 2.87 & -13.37 \\
\hline & $2 \sigma$ & 2.9 & 5.9 & 0.31 & 5.84 & 12.8 & 0.42 & 0.70 \\
\hline
\end{tabular}

$11.3 \times 10^{-5}$ and $16-39.3 \times 10^{-6}$, respectively. Iron and manganese show a weak positive correlation but no dependency on water depth. The content of sulfur in Hells Bells carbonate is constantly high with concentrations of $0.8-1.0 \mathrm{~g} \mathrm{~kg}^{-1}$ (Table S4) and mean S/Ca molar ratios of $2.87 \pm 0.42 \times 10^{-3}$, showing no dependency on water depth of the sample (Table 1).

\subsubsection{Hells Bells stable carbon isotopes}

Stable carbon isotope values of Hells Bells calcite samples $\left(\delta^{13} \mathrm{C}_{\text {calcite }}\right)$ from different water depth range from $-12.85 \%$ o to $-13.82 \%$ with a mean value of $-13.37 \%$ o $\pm 0.70 \%$ o $(n=9$, Table 1$)$. There is a weak correlation of increasing $\delta^{13} \mathrm{C}_{\text {calcite }}$ values with water depth of the samples (Fig. 6b). Furthermore, $\delta^{13} \mathrm{C}_{\text {calcite values show a strong negative corre- }}$ 

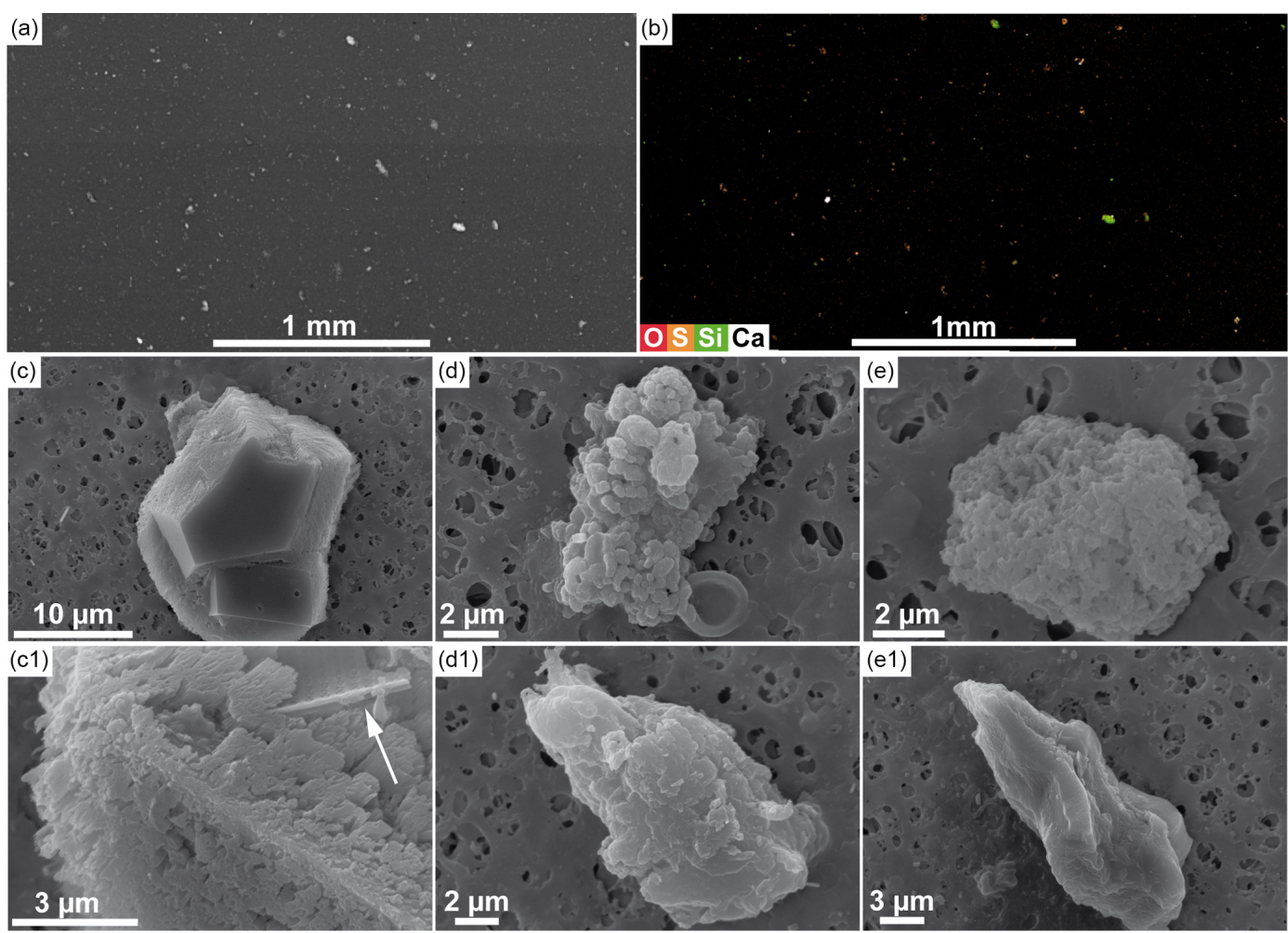

Figure 7. SEM analysis of turbid layer filtrate. Various particles on the filter are visible on the SEM picture of a larger area of the filter (a). An element map for $\mathrm{O}, \mathrm{S}, \mathrm{Si}$ and $\mathrm{Ca}$ of the same filter area of (a) is shown in (b) revealing that most particles consist of elemental sulfur, calcium-rich particles and silica particles. EDX analysis of individual particles on the filter verified the particles as calcium carbonates (c, c1), elemental sulfur (d, d1) and silicate phases (e, e1). The white arrow in c1 points to a fragmentary silica shell.

lation with $\mathrm{Sr} / \mathrm{Ca}$ and $\mathrm{Ba} / \mathrm{Ca}$ with $r^{2}$ values of 0.82 and 0.89 (Fig. 6a).

The stable carbon isotope ratio of the $\mathrm{HCO}_{3}^{-}$that is in equilibrium with the Hells Bells calcite $\left({ }^{13} \mathrm{C}_{-\mathrm{eq}} \mathrm{HCO}_{3}^{-}\right)$ at $25^{\circ} \mathrm{C}$ water temperature $\left(\delta^{13} \mathrm{C}_{\text {Calcite }}-0.91 \% o=\delta^{13} \mathrm{C}-\right.$ eq $\mathrm{HCO}_{3}^{-}$) was calculated after Mook (2000). The calculated $\delta^{13} \mathrm{C}_{-} \mathrm{eq} \mathrm{HCO}_{3}^{-}$is $-14.28 \%$ o $\pm 0.70 \%$, which is lower than the $\delta^{13} \mathrm{C}-\mathrm{HCO}_{3}^{-}$determined for the water column with a range of $-9.1 \%$ o to $-12.3 \%$.

\subsection{Turbid layer filtrate}

Although the turbid layer appears dense in photographs taken during dives, the water sampled from the turbid layer was clear, with no visible turbidity during sample handling. Electron microscopy of the filter, however, reveals that abundant particles were extracted from the turbid layer (Fig. 7a). Particle sizes range between 1 and $100 \mu \mathrm{m}$, but most are in the range of $1-10 \mu \mathrm{m}$. They consist of calcium carbonate crystals (Fig. 7c and c1), globular particles consisting of elemental sulfur (Fig. 7d and d1) and silicate particles of different compositions (Fig. 7e and e1). Also, numerous intact and broken shells of siliceous diatoms were found on the filter. Some calcite crystals incorporated broken parts of silica shells (Fig. 7c1).

\section{Discussion}

\subsection{Limnological and hydrological conditions in El Zapote cenote}

The water temperature profile (Fig. 3a) offers valuable clues on the hydrological conditions in the El Zapote cenote. Mixing of the water in the narrow cenote shaft from 0 to $30 \mathrm{~m}$ water depth is indicated by constant temperatures and oxygenation, whereas linearly increasing temperatures in the wide dome-shaped cenote from 30 to $55 \mathrm{~m}$ water depth and linearly decreasing dissolved oxygen concentrations indicate conductive heat transport and oxygen diffusion, respectively (Fig. 3a). This suggests that the water body from 0 to $30 \mathrm{~m}$ water depth is mixing-dominated and is diffusion-dominated at 30 to $>50 \mathrm{~m}$ water depth. This interpretation is also supported by constant EC values in the cenote shaft and constantly increasing EC values from $30 \mathrm{~m}$ water depth down to the top of the halocline at $36.8 \mathrm{~m}$ water depth (Fig. 3a). Another indication for stagnant conditions of the water body is the shape of the halocline itself. Compared to other cenotes of the Yucatán Peninsula being deep enough to reach the halocline, El Zapote cenote particularly differs in the extent of the halocline, the transition zone from fresh to saltwa- 
ter. At El Zapote cenote, the halocline is about $10 \mathrm{~m}$ thick (Fig. 3a) in comparison to a transition zone thickness of 1$5 \mathrm{~m}$ of other cenotes of Quintana Roo (Kovacs et al., 2017b; Stoessell et al., 1993).

The constant decrease of DIC, sulfide and orthophosphate below about $40 \mathrm{~m}$ water depth indicates a sink of these chemical species into depths greater than the cenote ( $>54 \mathrm{~m}$ water depth). This sink may result from advection of flowing water masses in conduits or zones of intensified hydraulic conductivity in a deeper cave system at around $60 \mathrm{~m}$ below the present sea level. Such deep cave systems could have developed during glacial sea level low stands (e.g., Smart et al., 2006).

In general, the water body of El Zapote cenote is stagnant from $30 \mathrm{~m}$ water depth down to the bottom of the cave where mass transfer is predominantly due to chemical diffusion. This is essential for the understanding of hydrogeochemistry and the ongoing biogeochemical processes in the El Zapote cenote.

\subsection{Hydrogeochemical processes in El Zapote cenote}

\subsubsection{Sedimentary biogeochemical processes}

The anaerobic conditions and high concentrations of metabolites such as $\mathrm{S}(-\mathrm{II})$ and $\mathrm{CH}_{4}$ can be attributed to anaerobic heterotrophic organic matter (OM) decay in the debris mound sediments. Both the debris mound and the cenote floor are covered with a relatively thick layer $(\sim 1 \mathrm{~m})$ of $\mathrm{OM}$, consisting of mostly leaves and other plant remains, according to the descriptions of the divers. As a consequence of stagnancy in the meromictic water body and oxygen deficiency on the cave bottom, this OM is respired by heterotrophic microorganisms in the sediment via anaerobic fermentative and respiratory pathways.

Anaerobic OM degradation by fermentation and sulfatereducing bacteria produce hydrogen and hydrogen sulfide (S(-II)), $\mathrm{CO}_{2}$ (DIC) and acidity, thus lowering the $\mathrm{pH}$. Elevated concentrations of DIC and $\mathrm{S}(-\mathrm{II})$ are found in the halocline (Fig. 3c), and low $\delta^{13} \mathrm{C}_{-} \mathrm{HCO}_{3}^{-}$indicates a microbial origin of the hydrogen carbonate (e.g., Mook, 2000) (Fig. 4). Additionally, $\mathrm{pH}$ values are more acidic in the halocline (Fig. 3a and b) and sulfate reduction is further supported by decreasing $\mathrm{SO}_{4}^{2-} / \mathrm{Cl}^{-}$ratios in the halocline of up to $32 \%$ compared to the seawater ratio of 5.2 (Fig. 3c) (Stoessell et al., 1993).

Methane-producing archaea (methanogens) metabolize degraded $\mathrm{OM}$ releasing $\mathrm{CH}_{4}$ and DIC. Although this pathway is less energy efficient than sulfate reduction, and methanogenesis is not expected in the presence of sulfate, methanogens may dominate in deeper parts of the sediments where sulfate is already consumed (e.g., Whiticar, 1999). Diffusion of $\mathrm{CH}_{4}$ from the sediment into the water column leads to $\mathrm{CH}_{4}$ concentrations of up to $25 \mu \mathrm{mol} \mathrm{L}{ }^{-1}$ identified in the halocline of El Zapote.

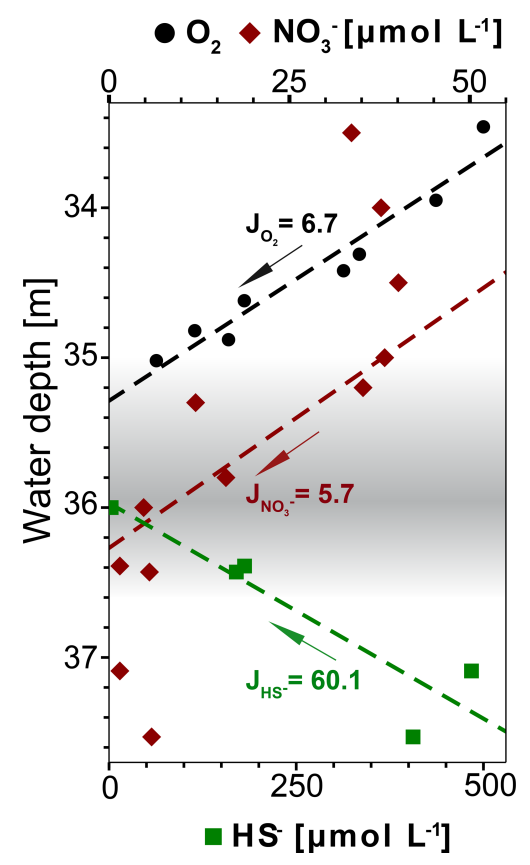

Figure 8. Concentration profiles of dissolved $\mathrm{O}_{2}, \mathrm{NO}_{3}^{-}$and $\mathrm{HS}^{-}$ (calculated with PHREEQC) in water depths around the redoxcline. The fluxes $J$ are given in $10^{-5} \mu \mathrm{mol} \mathrm{m}{ }^{-2} \mathrm{~s}^{-1}$. The linear fit of $\mathrm{O}_{2}$ and $\mathrm{HS}^{-}$is calculated for the range of plotted values, while for $\mathrm{NO}_{3}^{-}$it is calculated only for the range from 34.4 to $36.6 \mathrm{~m}$ water depth. Only $\mathrm{O}_{2}$ values above detection limit $\left(6.3 \mu \mathrm{mol} \mathrm{L}^{-1}\right)$ from winch profile 2 were considered for the calculation (Table S1).

Ammonium is likely released from organic matter degradation in the organic-rich sediment and is also released to the water column at the halocline.

Other common anaerobic heterotrophic metabolic pathways in sediments, such as the reduction of iron, are subordinated processes, most likely due to low concentrations of iron in limestone and limited source of siliciclastic materials in this part of the YP. The elevated but still exceedingly low amounts of dissolved iron in the halocline as compared to the freshwater body (Fig. S3) are rather not indicative of the absence of these processes, as iron solubility is limited by the affinity to form iron sulfides in the presence of high amounts of S(-II).

\subsubsection{Water column biogeochemical processes}

The redoxcline from 35 to $36.8 \mathrm{~m}$ water depth coincides with a peak in turbidity which is detectable both visually (Fig. 2b) and geochemically (Fig. 3a and b). Dissolved oxygen (DO) concentrations drop to undetectable levels at the top of the redoxcline, indicating that anaerobic biogeochemical processes prevail within the redoxcline (Fig. 8).

In our previous study we tentatively attributed these conditions to a full heterotrophic redox zonation due to organic matter decomposition (Stinnesbeck et al., 2017b). Fine or- 
ganic matter accumulates along the density contrast at the top of the halocline and heterotrophic microbial communities thrive from the aerobic and anaerobic decomposition of this organic matter. This is also indicated in the results of this study by minor nitrification from $\sim 34$ to $35 \mathrm{~m}$ water depth (Fig. 3b), non-linearly decreasing dissolved oxygen contents from $\sim 34$ to $35 \mathrm{~m}$, and by slightly more acidic $\mathrm{pH}$ values above and in the uppermost part of the turbid layer.

However, the more detailed data presented in this study now underline the importance of planktonic chemolithoautotrophic processes in the pelagic redoxcline which are driven by the upward diffusion of reduced sulfur, carbon and nitrogen species released from the anaerobic degradation of organic material at the cenote floor. Pelagic redoxclines develop in density stratified marine (e.g., Berg et al., 2015) as well as lake environments (e.g., Noguerola et al., 2015). In redoxclines below the photic zone the microbial community is dominated by chemolithoautotrophs, with a considerable amount of chemoautotrophic production and dark $\mathrm{CO}_{2}$ fixation (e.g., Grote et al., 2008; Jørgensen et al., 1991; Jost et al., 2010; Noguerola et al., 2015). The development of pelagic redoxclines was also reported for deep density stratified cenotes of the YP (e.g., Socki et al., 2002; Stoessell et al., 1993; Torres-Talamente et al., 2011).

In our previous study members of the Betaproteobacteria Hydrogenophilaceae and the Epsilonproteobacteria genus Sulfurovum were reported as dominant within the aqueous microbial community. Most members of these bacterial groups are chemolithotrophic or mixotrophic using reduced sulfur compounds or hydrogen as electron donors and oxygen or nitrogen compounds as electron acceptors (Stinnesbeck et al., 2017b).

The white cloudy turbid layer could be the result of a dense accumulation of these microorganisms, e.g., sulfur-oxidizing bacteria, analogous to that reported for Bundera sinkhole in Australia (Seymour et al., 2007). Elemental sulfur particles or polysulfides were detected on the turbid layer filtrate and indicate sulfur oxidation in the turbid layer or redoxcline (Sect. 3.4 and Fig. 7); these particles are formed as intermediates in the microbial oxidation of sulfide (Findlay, 2016).

The oxidation of sulfide in the redoxcline is likely anaerobic, as sulfide vanishes at around $36 \mathrm{~m}$ while dissolved oxygen is already at undetectable levels at $35 \mathrm{~m}$ water depth and both concentration profiles are not overlapping (Fig. 8). Furthermore, the oxygen flux towards the redoxcline is around one magnitude lower than the flux of the reduced sulfur species $\mathrm{HS}^{-}$, indicating that sulfide oxidation via aerobic pathways is minor (Fig. 8). Thus, sulfide oxidation within the redoxcline must be predominantly via anaerobic pathways. As the downward flux of $\mathrm{NO}_{3}^{-}$towards the redoxcline intersects with the upward flux of $\mathrm{HS}^{-}$(Fig. 8), assimilatory anaerobic sulfide oxidation could be obtained with nitrate as the terminal electron acceptor producing elemental sulfur and nitrogen under the consumption of protons (e.g., Bailey et al., 2009). The overall mass-balanced energy gener- ating reaction for chemoautotrophic nitrate-driven anaerobic sulfide oxidation (ND-SO) is given in Reaction (R1):

$7 \mathrm{HS}^{-}+2 \mathrm{NO}_{3}^{-}+\mathrm{CO}_{2}+9 \mathrm{H}^{+} \rightarrow$

$7 \mathrm{~S}^{0}+\mathrm{N}_{2}+\mathrm{CH}_{2} \mathrm{O}+7 \mathrm{H}_{2} \mathrm{O}$.

According to Reaction (R1) ND-SO could account to onethird of the $\mathrm{HS}^{-}$oxidation, despite the flux of $\mathrm{NO}_{3}^{-}$towards the redoxcline is around 1 order of magnitude lower than the $\mathrm{HS}^{-}$flux (Fig. 8). Furthermore ND-SO is proton-consuming and sulfide oxidation to elemental sulfur is more acid protonconsuming than the full sulfide oxidation to sulfate (see also Visscher and Stolz, 2005). The abundance of elemental sulfur particles found in the turbid layer filtrate (Fig. 7) indicates that sulfide oxidation to elemental sulfur is predominant. Full oxidation of sulfide to sulfate is less likely as no increase of sulfate is observed in the redoxcline (Fig. 3c). Maxima in $\mathrm{pH}$ are known to occur when sulfide is oxidized to elemental sulfur with nitrate as the electron acceptor (Kamp et al., 2006). Consequentially, the minimum amount of nitrate in the redoxcline and the slight alkaline $\mathrm{pH}$ shift, indicate that ND-SO is a relevant process in the redoxcline (Figs. 3b and $\mathrm{c}, 8)$. Therefore, the proton-consuming ND-SO could be the biogeochemical process in the redoxcline creating a disequilibrium in the carbonate dissolution-precipitation reaction, favoring calcite precipitation. This mechanism was recently reported for the formation of stromatolites below the photic zone of the Arabian Sea. There, a collective effect of proton-consuming ND-SO and alkalinity-producing sulfatedriven oxidation of $\mathrm{CH}_{4}$ (SD-OM) leads to authigenic carbonate precipitation in microbial mats in the vicinity of $\mathrm{CH}_{4}$ seeps (Himmler et al., 2018).

Anaerobic SD-OM (e.g., Bailey et al., 2009) is likely to occur at the redoxcline, as dissolved $\mathrm{CH}_{4}$ concentrations vanish at around the same depth of sulfide $(\sim 36.5 \mathrm{~m})$, and $\delta^{13} \mathrm{C}$ $\mathrm{CH}_{4}$ values show a strong peak towards higher values at the same water depth (Fig. 4).

Autotrophy also supports calcite precipitation by taking up $\mathrm{CO}_{2}$ for the synthesis of biomass (Castanier et al., 1999; Kosamu and Obst, 2009). Although a decrease of DIC is not observed at the redoxcline, chemolithoautotrophy is indicated by the $\delta^{13} \mathrm{C}_{-}-\mathrm{HCO}_{3}^{-}$in the water body (Fig. 4). The peak of higher values in the redoxcline indicates inorganic carbon assimilation by microorganisms (dark $\mathrm{CO}_{2}$ fixation). Organisms usually prefer to metabolize ${ }^{12} \mathrm{C}$ (it takes less energy to break the ${ }^{12} \mathrm{C}$ bond instead of ${ }^{13} \mathrm{C}$ ), which results in higher $\delta^{13} \mathrm{C}^{1}-\mathrm{HCO}_{3}^{-}$values in the remaining dissolved inorganic carbon. Hence, the peak towards more positive $\delta^{13} \mathrm{C}_{-} \mathrm{HCO}_{3}^{-}$values identified in the redoxcline of El Zapote at $\sim 36 \mathrm{~m}$ water depth may be attributed to microbial $\mathrm{CO}_{2}$ assimilation or dark $\mathrm{CO}_{2}$ fixation.

\subsection{Hypothesis on Hells Bells formation}

It was suspected before that Hells Bells form within the freshwater body of El Zapote cenote (Stinnesbeck et al., 
2017b). The depth zone of Hells Bells formation within the freshwater layer can now be narrowed down by the application of Eq. (2) with a given distribution coefficient $D(\mathrm{Mg})$ of the temperature-dependent partitioning of $\mathrm{Mg}$ into calcite.

$$
(\mathrm{Mg} / \mathrm{Ca})_{\text {solution }}=\frac{(\mathrm{Mg} / \mathrm{Ca})_{\text {solid }}}{D(\mathrm{Mg})}
$$

Applying the mean value of $\mathrm{Mg} / \mathrm{Ca}_{\text {solid }}$ determined for Hells Bells calcites (Table 1) and $D\left(\mathrm{Mg}\right.$ ) at $25^{\circ} \mathrm{C}$ given by Huang and Fairchild (2001) and Rimstidt et al. (1998), the calculation of $\mathrm{Mg} / \mathrm{Ca}_{\text {solution }}$ of the solution from which the Hells Bells calcite precipitated yields a $\mathrm{Mg} / \mathrm{Ca}$ solution of 0.73 and 1.06 , respectively. $\mathrm{Mg} / \mathrm{Ca}_{\text {solution }}$ ratios in this range are found in the water of the redoxcline and the uppermost top of the halocline in 36-37 m water depth, thus supporting the interpretation that Hells Bells formation takes place in the redoxcline (Fig. 3c and Table S4).

The calcite crystals found in the turbid layer filtrate give further information on calcite precipitation in the redoxcline (Fig. 7c). It is not yet known whether these particles represent autochthonous matter of the turbid layer. Nevertheless, formation of calcite crystals at the density boundary is likely, as fine particulate matter is accumulated there and may act as crystallization seeds. This process is indicated by calcite crystal formation around silica shells (Fig. 7c1). The high sulfur contents found in Hells Bells calcite also supports this assumption as small sulfur particles are abundant in this water layer and are easily enclosed in calcite crystals growing there (Table 1).

Based on the indications of Hells Bells formation in the redoxcline and taking the biogeochemical processes discussed before into account we propose the following scenario illustrated in Fig. 9. It summarizes the biogeochemical processes inducing calcite oversaturation and calcite precipitation in the turbid layer and the redoxcline of El Zapote cenote. Heterotrophic bacterial decomposition of organic matter in the sediment of the debris mound releases $\mathrm{CO}_{2}\left(\mathrm{HCO}_{3}^{-}\right)$, nutrients $\left(\mathrm{P}_{\text {ortho }}\right)$, and reduced species of sulfur $(\mathrm{S}(-\mathrm{II}))$ and nitrogen $\left(\mathrm{NH}_{4}^{+}\right)$. Due to the stagnant conditions in the cenote, these species are transported via diffusion, thereby allowing for the formation of a defined and stable redoxcline. Here, anaerobic chemolithoautotrophy, especially proton-consuming nitrate-driven sulfide oxidation (ND-SO), increase alkalinity, thus favoring calcite precipitation (Fig. 9). The required $\mathrm{Ca}^{2+}$ ions for calcite precipitation are constantly supplied to the redoxcline by upward diffusion from the calcium-enriched saline water body (Stinnesbeck et al., 2017b).

\subsubsection{Calcite precipitation rates}

In order to test the plausibility of the hypothesis on Hells Bells formation within the redoxcline, calcite precipitation rates of both biogeochemical processes, $\mathrm{ND}-\mathrm{SO}$ and $\mathrm{CO}_{2}$ as- similation are assessed. All used parameters and results are given in Table S5.

The overall chemical reaction of the carbonate balance is given in Reaction (R2), and the partial reactions are given in Reactions (R2a)-(R2d). Under equilibrium conditions, carbonate precipitation after Reaction (R2) is acid producing because for each mole of precipitated calcite in Reaction (R2) one proton is released to compensate for the abstracted carbonate ion (Reaction R2b) due to proton shift in the partial reactions (Reaction R2b-R2d).

$\mathrm{Ca}^{2+}+2 \mathrm{HCO}_{3}^{-} \leftrightarrow \mathrm{CaCO}_{3}+\mathrm{CO}_{2}+\mathrm{H}_{2} \mathrm{O}$

$\mathrm{Ca}^{2+}+\mathrm{CO}_{3}^{2-} \leftrightarrow \mathrm{CaCO}_{3}$

$\mathrm{HCO}_{3}^{-} \leftrightarrow \mathrm{CO}_{3}^{2-}+\mathrm{H}^{+}$

$\mathrm{HCO}_{3}^{-}+\mathrm{H}^{+} \leftrightarrow \mathrm{H}_{2} \mathrm{CO}_{3}$

$\mathrm{H}_{2} \mathrm{CO}_{3} \leftrightarrow \mathrm{CO}_{2}+\mathrm{H}_{2} \mathrm{O}$

The calcite precipitation rate $\mathrm{R}_{\mathrm{ND}-\mathrm{SO}}$ derived from ND-SO within the redoxcline can be estimated with Eq. (3) under the following assumptions: (i) up to one-third of the hydrogen sulfide flux towards the redoxcline (Fig. 8) is oxidized by the proton consuming ND-SO after Reaction (R1), and (ii) the proton consumption of this process is buffered by both the observed increase in $\mathrm{pH}$ values of 0.04 within the redoxcline (Fig. 3b) and calcite precipitation after Reaction (R2).

$R_{\mathrm{ND}-\mathrm{SO}}=\frac{1}{3} J_{\mathrm{HS}^{-}} \times\left(\frac{\alpha}{\mathrm{mHS}^{-}}-\frac{\beta}{\mathrm{mHS}^{-}}\right)\left[\mathrm{mol}\left(\mathrm{m}^{2} \mathrm{~s}\right)^{-1}\right]$

With $\mathrm{mHS}^{-}=7$ (moles of $\mathrm{HS}^{-}$in Reaction R1), $\alpha=9$ (moles of $\mathrm{H}^{+}$in Reaction R1) and $\beta=0.91$ (moles of $\mathrm{H}^{+}$ consumed in $\mathrm{pH}$ increase of 0.04).

Equation (3) yields that $7.3 \mathrm{mmol}$ calcite $\mathrm{m}^{-2} \mathrm{a}^{-1}$ or $0.73 \mathrm{~g}$ calcite $\mathrm{m}^{-2} \mathrm{a}^{-1}$ could be precipitated within the redoxcline due to ND-SO. This adds up to a total calcite precipitation rate $\mathrm{R}_{\mathrm{ND}-\mathrm{SO}}$ of $2.2-6.2 \mathrm{~kg}$ calcite $\mathrm{a}^{-1}$ in the whole redoxcline of the circular 60-100 $\mathrm{m}$ wide El Zapote cenote.

Additionally, the second biogeochemical process in the redoxcline that might lead to calcite precipitation, the $\mathrm{CO}_{2}$ assimilation or dark $\mathrm{CO}_{2}$ fixation (Fig. 9), has to be taken into account. Under equilibrium conditions, for each mole of abstracted or assimilated $\mathrm{CO}_{2}$ one proton is consumed due to the carbonate balance (Reactions R2a-R2d) and this proton consumption is compensated by calcite precipitation (Reaction R2). The $\mathrm{CO}_{2}$ assimilation rate in the redoxcline can be approached by the upward flux of $\left.\mathrm{DIC}\left(\mathrm{JIC}_{\mathrm{DICO}}\right)\right)$ towards the redoxcline (calculated as $\mathrm{HCO}_{3}^{-}$and given in Fig. S4).

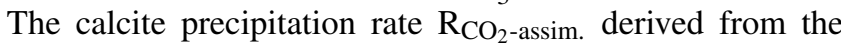
$\mathrm{CO}_{2}$ assimilation is then limited to the half of the DIC flux towards the redoxcline as given in Eq. (4).

$R_{\mathrm{CO}_{2} \text {-assim. }}=\frac{1}{2} J_{\mathrm{DIC}\left(\mathrm{HCO}_{3}^{-}\right)}$ 
Biogeochemical processes involved in Hells Bells formation

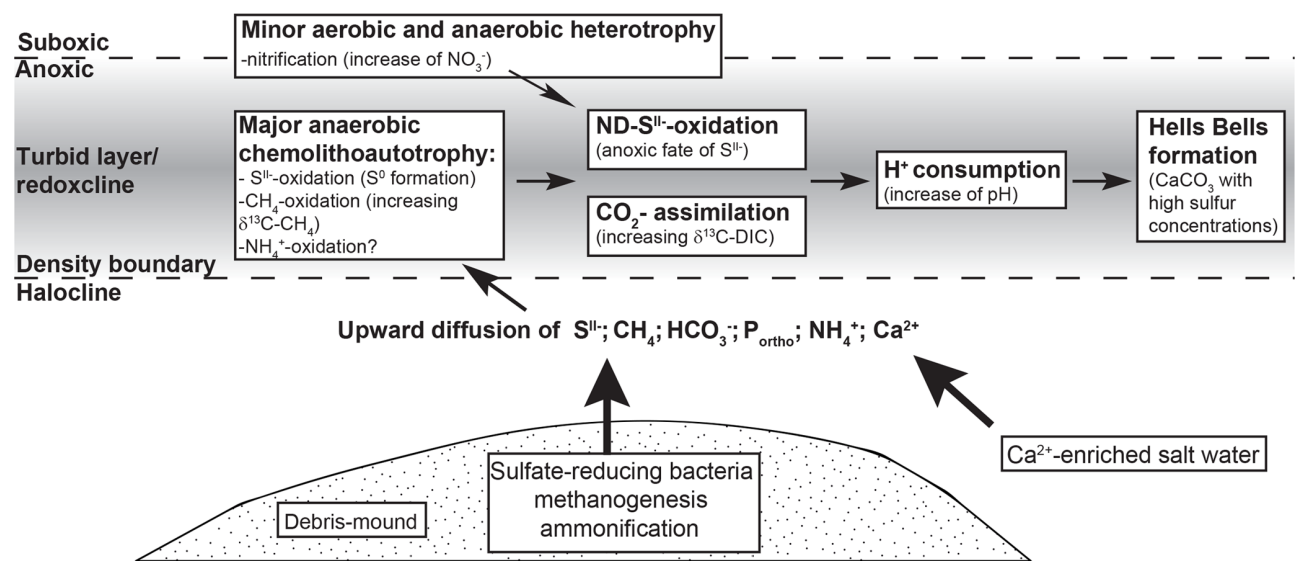

Figure 9. Scheme of the biogeochemical processes involved in the sediment and redoxcline of the water column of the El Zapote cenote that lead to Hells Bells formation.

Equation (4) yields a calcite precipitation rate $\mathrm{R}_{\mathrm{CO}_{2} \text {-assim. }}$ of $40 \mathrm{mmol}$ calcite $\mathrm{m}^{-2} \mathrm{a}^{-1}$, which is $12-34 \mathrm{~kg} \mathrm{a}^{-1}$ in the whole redoxcline. Such rates seem reasonable when compared to reported dark $\mathrm{CO}_{2}$ fixation rates from 0.2 to $2.7 \mu \mathrm{mol} \mathrm{CO} \mathrm{L}^{-1} \mathrm{~d}^{-1}$ of deep marine pelagic redoxclines in the Black Sea (Jørgensen et al., 1991), the Baltic Sea (Glaubitz et al., 2009; Jost et al., 2008) as well as for a deep karstic lake pelagic redoxcline (Noguerola et al., 2015) (Table S5). Applied to the redoxcline of El Zapote cenote, these rates would yield calcite precipitation rates from 11$420 \mathrm{~kg}$ calcite $\mathrm{a}^{-1}$ in the $0.5 \mathrm{~m}$ thick and $60-100 \mathrm{~m}$ wide redoxcline of the circular El Zapote cenote.

The summed up calcite precipitation rates of $\mathrm{R}_{\mathrm{ND}-\mathrm{SO}}$

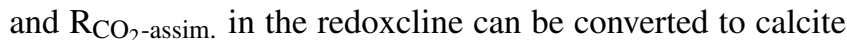
growth rates from 0.27 to $1.46 \mu \mathrm{m} \mathrm{a}^{-1} \mathrm{~m}^{-2}$, taking a calcite density of $2.7 \mathrm{~g} \mathrm{~cm}^{-3}$ into account. Calcite growth, however, is likely to be concentrated on a much smaller area, i.e., the crystal or substrate surfaces of Hells Bells hanging in the redoxcline, the cenote walls and the tree stem within the redoxcline (Figs. 2 and 3). This would result in a higher actual calcite growth rate; for example if the calcite growth is concentrated to $1 \%$ of the redoxcline area, this would result in actual growth rates of $27-146 \mu \mathrm{m} \mathrm{a}^{-1}$.

These growth rates are close to the reported net growth rates of $12-90 \mu \mathrm{m} \mathrm{a}^{-1}$ for a U-series dated Hells Bells specimen from the tree (Stinnesbeck et al., 2017b) demonstrating the plausibility of Hells Bells formation by the biogeochemical mechanisms proposed in this study. However, the actual calcite growth rates must be significantly higher than the reported net growth rates as these rates also comprise repeated phases of calcite dissolution (see Sect. 3.1.1 and 3.2; Stinnesbeck et al., 2017b).

Eventually, the comparison of the estimated actual calcite precipitation rates in the redoxcline and the reported net growth rates is hindered by a lack of data of both the actual area of calcite precipitation and the time and intensity of calcite dissolution.

\subsubsection{The role of halocline elevation in Hells Bells formation}

Hells Bells formed in modern to at least historic times and occur in a relatively thick vertical zone of about $10 \mathrm{~m}$ at 28 to $38 \mathrm{~m}$ water depth (Stinnesbeck et al., 2017b). This indicates that their underwater growth occurred under environmental conditions similar to the ones detected by us, as modern sea levels were already reached at about $4.5 \mathrm{ka}$ (Hengstum et al., 2010) and thus significantly earlier. Hells Bells therefore precipitate either permanently in the entire depth zone reaching from 28 to $38 \mathrm{~m}$, or in the narrow 1-2 $\mathrm{m}$ thick redoxcline or turbid layer above the halocline (Fig. 9). According to the data presented here the latter hypothesis appears much more likely to us. Therefore, we propose that growth of Hells Bells is a non-permanent episodic process which majorly depends on the halocline elevation in the cenote (Fig. 10). The depth of the halocline generally increases with increasing distance to the coast (Fig. 10a) (e.g., Bauer-Gottwein et al., 2011). The halocline depth position is a function of the hydrostatic pressure of the overlying freshwater layer, i.e., its thickness and the sea level. Therefore, the halocline elevation can vary on multiple timescales in response to droughts, recharge events and annual tidal fluctuations that are superimposed upon on a longer-term sea level change. Extensive droughts occurred repeatedly in the Holocene (Hodell et al., 2001) and could have led to a prolonged elevation of the halocline as the freshwater layer was thinner as a consequence of decreased precipitation (Evans et al., 2018). Although on much shorter timescales, extraordinary recharge events (e.g., hurricanes) must have an effect on the depth position of the halocline (Fig. 10b). Generally, during these events of enormous precipitation, the halocline is temporarily pushed downwards 


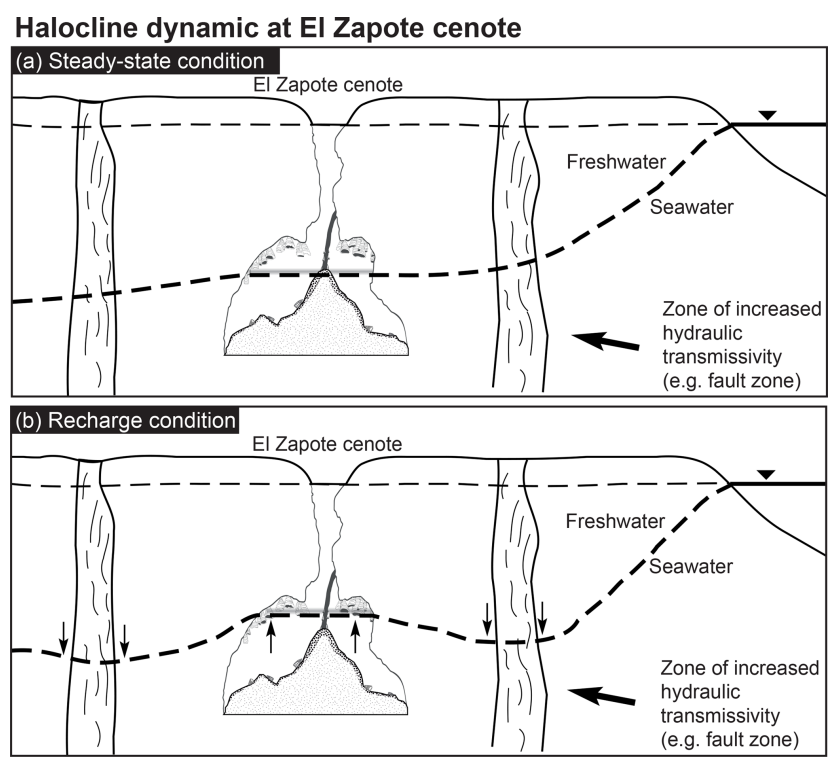

Figure 10. Sketch of dynamic halocline elevation within the Yucatán karst aquifer. Halocline depth increases with increasing distance from the coast in a steady-state condition (a). Recharge events result in a lower halocline beneath areas of high vertical transmissivities and an elevated halocline in areas of low hydraulic transmissivity, e.g., El Zapote cenote (b).

by the amount of the freshwater infiltrating into the Yucatán karst aquifer. However, it has been reported that the halocline can also be elevated as a response to precipitation events (Escolero et al., 2007).

Regionally and locally, vertical and lateral hydraulic transmissivities of both the epikarst and the phreatic karst can result in spatially variable hydraulic pressure of the freshwater lens (Williams, 1983), thus leading to a lowered halocline beneath areas of higher, and an elevated halocline beneath areas of less vertical hydraulic transmissivity. El Zapote cenote is located in the Holbox fracture zone that in the area is characterized by north-to-south trending lineaments of increased permeability (Bauer-Gottwein et al., 2011, and references therein). Hurricanes that pass the area frequently (Farfán et al., 2014) could therefore lead to episodic elevation of the halocline (Fig. 10).

Both a prolonged halocline elevation during droughts and short-term but frequent recharge-driven halocline elevations could result in the presence of Hells Bells in a zone of 28$38 \mathrm{~m}$ water depth. Furthermore, repeated phases of precipitation and dissolution indicated by the alternating layers of dogtooth calcite and microcrystalline calcite of Hells Bells thin sections (Stinnesbeck et al., 2017b) suggest an episodic halocline elevation. During episodes of an elevated halocline, precipitation or dissolution of Hells Bells may occur in lower depths due to the concurrent elevation of the calcite precipitating redoxcline and the underlying sulfide-rich and carbonate undersaturated water.
A variable halocline depth position at El Zapote cenote is also supported by the positive correlation with water depth of $\mathrm{Sr} / \mathrm{Ca}$ and a negative correlation of $\delta^{13} \mathrm{C}_{\text {calcite }}$ of the Hells Bells calcite (Fig. 6). Hells Bells formed in lower water depths show slightly higher contents of the trace elements $\mathrm{Sr}$, $\mathrm{Mg}$ and $\mathrm{Ba}$, and slightly lower $\delta^{13} \mathrm{C}_{\text {calcite values than Hells }}$ Bells formed in greater water depths (Table 1 and Fig. 6). The higher incorporation of the trace elements $\mathrm{Sr}, \mathrm{Mg}$ and $\mathrm{Ba}$ is either obtained by faster growth rates (Tesoriero and Pankow, 1996) or by elevated concentrations in the solution from which the calcite precipitated. The latter process is more likely, as the amount of saltwater increases in the turbid layer when the halocline is located at lower water depths. Lower $\delta^{13} \mathrm{C}_{\text {calcite }}$ values support this assumption, as lowest $\delta^{13} \mathrm{C}^{-} \mathrm{HCO}_{3}^{-}$values are detected in the halocline of the modern El Zapote cenote (Fig. 4).

The increase in saltwater in the lowermost freshwater and the turbid layer could result from increased salinity of the freshwater body during droughts. Furthermore, turbulences induced by a halocline elevation as a reaction to recharge events could increase the salinity of the lowermost freshwater body (Kovacs et al., 2017b). Minor mixing of the water bodies would be sufficient to increase the concentrations of $\mathrm{Sr}, \mathrm{Mg}, \mathrm{Ba}$ and decrease $\delta^{13} \mathrm{C}_{-} \mathrm{HCO}_{3}^{-}$in the turbid layer, as seen at El Zapote.

Following the model of an episodic halocline elevation, the question remains why Hells Bells are restricted to a zone of 28-38 m water depth. This range could solely depend on the hydraulic conditions, e.g., Hells Bells formation reflecting maximum and minimum elevations of the halocline as a result of droughts, recharge events and long-term sea level changes. The lower $(38 \mathrm{~m})$ level of Hells Bells formation may represent the stable environmental conditions in the modern El Zapote cave, influenced only by the thickness of the freshwater body and the mean sea level. The upper range boundary, on the other hand, could well be given by the shape of the sinkhole and limnological conditions in the narrow cenote shaft reaching from 0 to $30 \mathrm{~m}$ water depth. In this latter unit, the water body is mixing-dominated rather than diffusion-dominated (Fig. 3, Sect. 4.1). A rise of the halocline to about $28 \mathrm{~m}$ water depth would therefore lead to an exposure to fast and convective oxygen supply from the mixed freshwater body above, and consequently to aerobic microbial sulfide oxidation, which is an acid-producing reaction (e.g., Jones et al., 2015). Hells Bells formation would then stop as it is tied to anaerobic ND-SO. The occurrence of a zone of brown-colored manganese oxide coatings on Hells Bells and the cave wall at and above $30 \mathrm{~m}$ water depth indicates that the redoxcline must temporarily have reached up to this level (Figs. 2c, d and S6). Manganese dissolved in the halocline and turbid layer was then oxidized to manganese oxide precipitates (Fig. S6).

The dynamic history of halocline elevation at El Zapote cenote cannot be resolved to date but raises an interesting issue of further research on the dynamic hydraulic response of 
the Yucatán aquifer to extraordinary recharge events, especially as this process could be a key factor for the formation of Hells Bells. We are currently addressing this issue by logging the hydraulic head of the freshwater body and the electrical conductivity at a fixed position in the halocline of $\mathrm{El}$ Zapote cenote.

\subsubsection{Shape of Hells Bells}

Previously, we attributed the growth of Hells Bells to microbial mediation (Stinnesbeck et al., 2017b). We hypothesized that autotrophy (ammonia oxidation) and denitrification are the main factors that trigger calcite precipitation at the surface of the Hells Bells and that calcite precipitation could further be supported by the presence of negatively charged extracellular polymeric substances (EPS), leading to the accumulation of $\mathrm{Ca}^{2+}$ ions and to supersaturation of calcite within biofilms (e.g., Dupraz et al., 2009). However, the large size and form of the dogtooth calcite crystals of Hells Bells resemble slow-growing inorganic calcite crystals rather than biologically mediated precipitates (Figs. 2e and 5). This hypothesis is supported by Bosak and Newman (2005), who investigated microbial kinetic controls on calcite morphology and found that microbially mediated calcite precipitated at low calcite supersaturation shows more anhedral crystal morphologies, compared to the more euhedral abiotic ones. Although the microbial activity in the redoxcline induces calcite oversaturation, the hypothesis presented in this study is compatible with an inorganic calcite precipitation of the Hells Bells from a biologically mediated water layer.

Ultimately, the hypothesis of a dynamic halocline elevation and biogeochemically induced calcite precipitation in the redoxcline can be integrated to explain some morphological features of the Hells Bells. They grow downward and are conically divergent, with a strict horizontally lower margin and a hollow interior. Specimens also tend to be oriented towards the cenote center (Stinnesbeck et al., 2017b). The horizontal downward growth is indicative of a precipitation from a defined layer within the water column (i.e., the redoxcline). Also, an abrupt elevation of the redoxcline as a response to recharge events and a subsequent decelerated drop towards its original position serves to explain the downward growth of Hells Bells. This is indicated by the tendency towards downward orientation of the calcite crystal growth axis (Fig. 2e). The fact that Hells Bells specimens growing on the inclined cave wall are always oriented towards the cenote center could result from a lateral gradient in the chemolithoautotrophic intensity. The "energy sources" used by the chemolithotrophic microbial community in the redoxcline are the released reduced carbon, sulfur and nitrogen species from anaerobic organic matter decay in the organic-rich sediments on the debris mound. Both the morphology of the cenote and the diffusive mass transport likely result in radial concentration gradients of upwards diffusing reduced species from the sediment of the debris mound.
These conditions limit the availability of reduced species in locations of the redoxcline distal to the debris mound and vice versa. Consequently, the intensity of chemolithoautotrophy, and hence calcite oversaturation, is preferentially higher in the center proximal to the debris mound and decreases towards the cenote walls. This accounts for both the inclined bells as well as for horseshoe-like horizontal openings of Hells Bells which always face towards the wall. Furthermore, the often observed hollow interior of Hells Bells could be due to preferential growth of the outer edges of Hells Bells, especially the parts facing towards the cenote center. Once such parts of Hells Bells grow slightly more, hence into deeper water depth, this will result in a higher net growth as these parts are likely to be reached more frequently by the narrow zone of calcite precipitation (redoxcline). The conical shape and downward divergence of Hells Bells could be a continuation from the microscopic to the macroscopic level as the angles of the botryoidal calcite phases in the thin section (Fig. S5) strongly resemble those of the large specimens of Hells Bells (Fig. 2d).

Nevertheless, we can also not exclude the potential influence of microorganisms forming a biofilm community on the surface of Hells Bells. Stinnesbeck et al. (2017b) showed that this community does not resemble the planktonically growing microbial biocenosis but forms a distinct community that seems to thrive catalyzing the reduction and oxidation of different nitrogen species. However, to date it is not known what percentage the activity of these organisms contributes to the shape of the speleothems.

\subsection{Prerequisites for the formation of Hells Bells}

Hells Bells have so far been identified in a few cenotes only within a restricted area of the northeastern YP (Stinnesbeck et al., 2017b), although the peninsula hosts many thousands of sinkholes (Bauer-Gottwein et al., 2011). Thus, the following question arises: which factors are needed for the generation of these underwater speleothems? The following apparent prerequisites for Hells Bells formation appear likely to us:

- The cenote or sinkhole must be deep enough to reach the halocline in order to have a density stratified water column (meromixis).

- Sufficient input of organic material to the cenote bottom is required to create anoxia in the halocline with a release of reduced sulfur, carbon and nitrogen species.

- A meromictic stagnant water body indicated by a thick halocline is needed that allows for the formation of a redoxcline in which anaerobic chemolithoautotrophy prevails. This leads to a narrow zone of calcite oversaturation in the water body. 
- Special hydraulic conditions are needed which allow the halocline to rise and fall in order to form subaqueous speleothems.

\section{Conclusion}

The unique underwater speleothems termed Hells Bells recently described from El Zapote west of Puerto Morelos on the northern Yucatán Peninsula, Mexico, are most likely formed in the redoxcline, a narrow layer in the lowermost freshwater body immediately overlying the halocline. We propose a biogeochemical mechanism for the formation of these structures that induces calcite oversaturation favoring calcite precipitation within the redoxcline. The upward diffusion of reduced sulfur, carbon and nitrogen stimulates a chemolithoautotrophic microbial community thriving above the halocline at El Zapote cenote. Chemolithoautotrophy and proton-consuming nitrate-driven anaerobic sulfide oxidation (ND-SO) lead to calcite precipitation, and hence Hells Bells formation, in a narrow depth zone confined to the redoxcline, or turbid layer. We further postulate a dynamic elevation of the halocline as an episodic hydraulic response to both droughts and recharge events that may account for Hells Bells occurrence over a vertical range of $10 \mathrm{~m}$ water depth.

Data availability. The raw data of the figures and tables presented in this paper can be found in the Supplement.

Video supplement. The video supplement is available at: https://doi.org/10.5446/39353. The video gives an impression of the Hells Bells and the sampling at El Zapote cenote in December 2017, recorded by underwater videographer Thomas Vogt and edited by Simon Ritter.

Supplement. The supplement related to this article is available online at: https://doi.org/10.5194/bg-16-2285-2019-supplement.

Author contributions. SR developed the hypotheses equally supported by CS and MIS. SR visualized the data and prepared the original draft, MIS supervised. WS and AGG initialized the project and funding was acquired by WS, AGG and MIS. Sampling was planned and conducted by SR and CS. Instrumentation and methodology was provided by MIS for hydrogeochemical analyses and FK for gas and stable carbon isotope analysis. SR, LK and NS collected the data and CS, MIS, FK validated it. SR, CS, MIS, LK, NS interpreted the results. JG, WS and FK critically reviewed the paper.

Competing interests. The authors declare that they have no conflict of interest.
Acknowledgements. We gratefully acknowledge the owners of Cenote Zapote Ecopark: Rosario Fátima González Alcocer and Santos Zuñiga Roque, and their team members, Daniel de Jesus Tum Canul, Israel Mendez Castro and Eunice Mendez Castro de la Cruz, for granting us access to the cenote and their great support during field work. We would like to thank the technical cave divers Eugenio Aceves Núñez, Christine Loew, Dirk Penzel and Thomas Vogt for their excellent work in retrieving samples from El Zapote cenote. Many thanks to Vicente Fito, the original El Zapote cenote explorer for sharing his discovery. We thank Markus Greule, Bernd Knape, Silvia Rheinberger and Swaantje Brzelinski for conducting geochemical analyses and Stefan Rheinberger in particular for many discussions that helped to produce and improve this dataset. We are grateful for the help of Alexander Varychev, Anne Hildenbrand and Gregor Austermann with the optical analyses and thank Tianxiao Sun for examining the thin sections. We are grateful for the effort of the technicians Christian Mächtel and Andreas Thum of the Institute of Earth Sciences for their technical and constructional support prior to the field trip. Finally, we thank Jan Hartmann, Andrea Schröder-Ritzrau, Tobias Anhäuser and Daniela Polag for their sincere proofreading and many fruitful discussions during lunch and coffee breaks. Finally, we are grateful for the valuable comments and suggestions of the two anonymous referees which helped to improve the original version of the paper.

We acknowledge the financial support by Deutsche Forschungsgemeinschaft within the funding program Open Access Publishing, by the Baden-Württemberg Ministry of Science, Research and the Arts and by Ruprecht-Karls-Universität Heidelberg.

Financial support. This research has been supported by the Deutsche Forschungsgemeinschaft (grant no. STI128/28), the Deutsche Forschungsgemeinschaft (grant no. STI128/36), and the CONACYT-FONCICYT-DADC (grant no. 000000000278227).

Review statement. This paper was edited by S. Wajih A. Naqvi and reviewed by two anonymous referees.

\section{References}

Back, W., Hanshaw, B. B., Herman, J. S., and Van Driel, J. N.: Differential dissolution of a Pleistocene reef in the ground-water mixing zone of coastal Yucatan, Mexico, Geology, 14, 137-140, 1986.

Bailey, J. V, Orphan, V. J., Joye, S. B., and Corsetti, F. A.: Chemotrophic Microbial Mats and Their Potential for Preservation in the Rock Record, Astrobiology, 9, 843-859, 2009.

Barton, H. A. and Northup, D. E.: Geomicrobiology in Cave Environments: Past, current and future Perspectives, J. Cave Karst Stud., 69, 163-178, 2007.

Bauer-Gottwein, P., Gondwe, B. R. N., Charvet, G., Marín, L. E., Rebolledo-Vieyra, M., and Merediz-Alonso, G.: Review?: The Yucatán Peninsula karst aquifer, Mexico, Hydrol. J., 19, 507524, https://doi.org/10.1007/s10040-010-0699-5, 2011.

Beddows, P. A., Smart, P. L., Whitaker, F. F., and Smith, S. L.: Density stratified groundwater circulation on the Caribbean Coast of Yucatan peninsula, Mexico, in: Karst Waters Institute Spe- 
cial Publication 7: Hydrogeology and Biology of Post-Paleozoic Carbonate Aquifers, edited by: Martin, J. B., Wicks, C. M., and Sasowsky, I. D., 129-134., 2002.

Beddows, P. A., Smart, P. L., Whitaker, F. F., and Smith, S. L.: Decoupled fresh-saline groundwater circulation of a coastal carbonate aquifer: Spatial patterns of temperature and specific electrical conductivity, J. Hydrol., 346, 18-32, https://doi.org/10.1016/j.jhydrol.2007.08.013, 2007.

Berg, C., Vandieken, V., Thamdrup, B., and Ju, K.: Significance of archaeal nitrification in hypoxic waters of the Baltic Sea, ISME J., 9, 1319-1332, https://doi.org/10.1038/ismej.2014.218, 2015.

Bontognali, T. R. R., Angeli, I. M. D., Tisato, N., Vasconcelos, C., Bernasconi, S. M., Gonzales, E. R. G., and De Waele, J.: Mushroom Speleothems: Stromatolites That Formed in the Absence of Phototrophs, Fontiers Earth Sci., 4, 1-8, https://doi.org/10.3389/feart.2016.00049, 2016.

Bosak, T. and Newman, D. K.: Microbial Kinetic Controls on Calcite Morphology in Supersaturated Solutions, J. Sediment. Res., 75, 190-199, https://doi.org/10.2110/jsr.2005.015, 2005.

Castanier, S., Métayer-Levrel, G., and Perthuisot, J.-P.: Cacarbonates precipitation and limestone genesis - the microbiogeologist point of view, Sediment. Geol., 126, 9-23, 1999.

Dupraz, C., Reid, R. P., Braissant, O., Decho, A. W., Norman, R. S., and Visscher, P. T.: Processes of carbonate precipitation in modern microbial mats, Earth-Sci. Rev., 96, 141-162, https://doi.org/10.1016/j.earscirev.2008.10.005, 2009.

Escolero, O., Marin, L. E., Domínguez-Mariani, E., and TorresOnofre, S.: Dynamic of the freshwater - saltwater interface in a karstic aquifer under extraordinary recharge action?: the Merida Yucatan case study, Environ. Geol., 51, 719-723, https://doi.org/10.1007/s00254-006-0383-1, 2007.

Evans, N. P., Bauska, T. K., Gázquez-sánchez, F., Brenner, M., Curtis, J. H., and Hodell, D. A.: Quantification of drought during the collapse of the classic Maya civilization, Science, 361, 498-501, 2018.

Farfán, L. M., D’Sa, E. J., Liu, K. and Rivera-Monroy, V.: Tropical Cyclone Impacts on Coastal Regions?: the Case of the Yucatán and the Baja California Peninsulas, Mexico, Estuar. Coast., 37, 1388-1402, https://doi.org/10.1007/s12237-014-9797-2, 2014.

Findlay, A. J.: Microbial impact on polysulfide dynamics in the environment, FEMS Microbiol. Lett., 363, 1-12, https://doi.org/10.1093/femsle/fnw103, 2016.

Glaubitz, S., Lueders, T., Abraham, W., Jost, G., Jürgens, K., and Labrenz, M.: ${ }^{13} \mathrm{C}$-isotope analyses reveal that chemolithoautotrophic Gamma- and Epsilonproteobacteria feed a microbial food web in a pelagic redoxcline of the central Baltic Sea, Environ. Microbiol., 11, 326-337, https://doi.org/10.1111/j.14622920.2008.01770.x, 2009.

Gradzinski, M., Chmiel, M. J., and Motyka, J.: Formation of calcite by chemolithoautotrophic bacteria - a new hypothesis on microcrystalline cave pisoids, Ann. Soc. Geol. Pol., 82, 361-369, 2012.

Grote, J., Labrenz, M., Herndl, G. J., and Ju, K.: Epsilonproteobacteria Represent the Major Portion of Chemoautotrophic Bacteria in Sulfidic Waters of Pelagic Redoxclines of the Baltic and Black Seas, Appl. Environ. Microbiol., 74, 7546-7551, https://doi.org/10.1128/AEM.01186-08, 2008.

Guido, A., Heindel, K., Birgel, D., Rosso, A., Mastandrea, A., San, R., Russo, F., and Peckmann, J.: Pendant bioconstructions cemented by microbial carbonate in submerged marine caves
(Holocene, SE Sicily), Palaeogeogr. Palaeocl., 388, 166-180, https://doi.org/10.1016/j.palaeo.2013.08.007, 2013.

Gulley, J. D., Martin, J. B., and Brown, A.: Organic carbon inputs, common ions and degassing?: rethinking mixing dissolution in coastal eogenetic carbonate aquifers, Earth Surf. Proc. Land., 41, 2098-2110, https://doi.org/10.1002/esp.3975, 2016.

Hengstum, P. J. Van, Reinhardt, E. G., Beddows, P. A., and Gabriel, J. J.: Linkages between Holocene paleoclimate and paleohydrogeology preserved in a Yucatan underwater cave, Quaternary Sci. Rev., 29, 2788-2798, https://doi.org/10.1016/j.quascirev.2010.06.034, 2010.

Himmler, T., Smrzka, D., Zwicker, J., Kasten, S., Shapiro, R. S., and Bohrmann, G.: Stromatolites below the photic zone in the northern Arabian Sea formed by calcifying chemotrophic microbial mats, Geology, 46, 2-5, 2018.

Hodell, D. A., Brenner, M., Curtis, J. H., and Guilderson, T.: Solar Forcing of Drought Frequency in the Maya Lowlands, Science, 292, 1367-1371, 2001.

Holmes, A. J., Tujula, N. A., Holley, M., Contos, A., James, J. M., Rogers, P., and Gillings, M. R.: Phylogenetic structure of unusual aquatic microbial formations in Nullarbor caves, Australia, Environ. Microbiol., 3, 256-264, 2001.

Huang, Y. and Fairchild, I. J.: Partitioning of Sr2+ and $\mathrm{Mg} 2+$ into calcite under karst-analogue experimental conditions, Geochim Cosmochim. Ac., 65, 47-62, https://doi.org/10.1016/S00167037(00)00513-5, 2001.

Jones, D. S., Lyon, E. H., and Macalady, J. L.: Geomicrobilogy of biovermiculations from the Frasassi cave system, Italy, J. Cave Karst Stud., 70, 78-93, 2008.

Jones, D. S., Albrecht, H. L., Dawson, K. S., Schaperdoth, I., Freeman, K. H., Pi, Y., Pearson, A., and Macalady, J. L.: Community genomic analysis of an extremely acidophilic sulfur-oxidizing biofilm, ISME J., 6, 158-170, https://doi.org/10.1038/ismej.2011.75, 2012.

Jones, D. S., Polerecky, L., Galdenzi, S., Dempsey, B. A., and Macalady, J. L.: Fate of sulfide in the Frasassi cave system and implications for sulfuric acid speleogenesis, Chem. Geol., 410, 21-27, https://doi.org/10.1016/j.chemgeo.2015.06.002, 2015.

Jørgensen, B. B., Fossing, H., Wirsent, C., and Jannasch, H.: Sulfide oxidation in the anoxic Black Sea chemocline, Deep-Sea Res. 38, 1083-1103, https://doi.org/10.1016/S0198-0149(10)800251,1991

Jost, G., Zubkov, M. V., Yakushev, E., Labrenz, M., and Jürgens, K.: High abundance and dark $\mathrm{CO}_{2}$ fixation of chemolithoautotrophic prokaryotes in anoxic waters of the Baltic Sea, Limnol. Oceanogr., 53, 14-22, 2008.

Jost, G., Martens-Habbena, W., Pollehne, F., Schnetger, B., and Labrenz, M.: Anaerobic sulfur oxidation in the absence of nitrate dominates microbial chemoautotrophy beneath the pelagic chemocline of the eastern Gotland Basin, Baltic Sea, FEMS Microbiol. Ecol., 71, 226-236, https://doi.org/10.1111/j.15746941.2009.00798.x, 2010.

Kamp, A., Stief, P., and Schulz-Vogt, H. N.: Anaerobic Sulfide Oxidation with Nitrate by a Freshwater Beggiatoa Enrichment Culture, Appl. Environ. Microbiol., 72, 4755-4760, https://doi.org/10.1128/AEM.00163-06, 2006.

Keppler, F., Laukenmann, S., Rinne, J., Heuwinkel, H., Greule, M., Whiticar, M., and Lelieveld, J.: Measurements of 13C/12C Methane from Anaerobic Digesters: Comparison of Optical 
Spectrometry with Continuous-Flow Isotope Ratio Mass Spectrometry, Environ. Sci. Technol., 44, 5067-5073, 2010.

Kosamu, I. B. M. and Obst, M.: The influence of picocyanobacterial photosynthesis on calcite precipitation, Int. J. Environ. Sci. Technol., 6, 557-562, 2009.

Kovacs, S. E., Reinhardt, E. G., Chatters, J. C., Rissolo, D., Schwarcz, H. P., Collins, S. V., Kim, S., Blank, N. A., and Erreguerena, P. L.: Calcite raft geochemistry as a hydrological proxy for Holocene aquifer conditions in Hoyo Negro and Ich Balam (Sac Actun Cave System), Quintana Roo, Mexico, Quaternary Sci. Rev., 175, 97-111, https://doi.org/10.1016/j.quascirev.2017.09.006, 2017a.

Kovacs, S. E., Reinhardt, E. G., Stastna, M., Coutino, A., Werner, C., Collins, S. V., Devos, F., and Le Maillot, C.: Hurricane Ingrid and Tropical Storm Hanna's effects on the salinity of the coastal aquifer, Quintana Roo, Mexico, J. Hydrol., 551, 703-714, https://doi.org/10.1016/j.jhydrol.2017.02.024, 2017b.

Laukenmann, S., Polag, D., Heuwinkel, H., Greule, M., Gronauer, A., Lelieveld, J., and Keppler, F.: Identification of methanogenic pathways in anaerobic digesters using stable carbon isotopes, Eng. Life Sci., 10, 509-514, 2010.

Lefticariu, M., Perry, E. C., Ward, W. C., and Lefticariu, L.: PostChicxulub depositional and diagenetic history of the northwestern Yucatan Peninsula, Mexico, Sediment. Geol., 183, 51-69, https://doi.org/10.1016/j.sedgeo.2005.09.008, 2006

Macalady, J. L., Jones, D. S., and Lyon, E. H.: Extremely acidic, pendulous cave wall biofilms from the Frasassi cave system, Italy, Environ. Microbiol., 9, 1402-1414, https://doi.org/10.1111/j.1462-2920.2007.01256.x, 2007.

Macintyre, I. G.: Extensive submarine lithification in a cave in the Belize Barrier Reef Platform, J. Sediment. Petrol., 54, 221-235, 1984.

Melim, L. A., Shinglman, K. M., Boston, P. J., Northup, D. E., Spilde, M. N., and Queen, M. J.: Evidence for Microbial Involvement in Pool Finger Precipitation, Hidden Cave, New Mexico, Geomicrobiol. J., 18, 311-239, https://doi.org/10.1080/01490450152467813, 2001.

Mook, W. G. (Ed.): Environmental isotopes in the hydrological cycle, UNESCO/IAEA, IHP-V Technical Documents in Hydrology No. 39, Vol. 1, Paris, 2000.

Moore, Y. H., Stoessell, R. K., and Easley, D. H.: Fresh-Water/SeaWater relationship within a Ground-Water flow system northeastern coast of the yucatan, Ground Water, 30, 343-350, 1992.

Mylroie, J. E. and Carew, J. L.: The flank margin model for dissolution cave development in carbonate platforms, Earth Surf. Proc. Land., 15, 413-424, 1990.

Noguerola, I., Picazo, A., Llir, M., Camacho, A., and Borrego, C. M.: Diversity of freshwater Epsilonproteobacteria and dark inorganic carbon fixation in the sulphidic redoxcline of a meromictic karstic lake, FEMS Microbiol. Ecol., 91, 1-15, https://doi.org/10.1093/femsec/fiv086, 2015.

Parkhurst, B. D. L. and Appelo, C. A. J.: User's guide to PHREEQC (Version 2): a computer program for speciation, batch-reaction, one-dimensional transport, and inverse geochemical calculations, Water-Resources Investigations Report, 994259, https://doi.org/10.3133/wri994259, 1999.

Paul, D., Skrzypek, G., and Forizs, I.: Normalization of measured stable isotopic compositions to isotope reference scales
- a review, Rapid Commun. Mass Sp., 21, 3006-3014, https://doi.org/10.1002/rcm.3185, 2007.

QRSS: Quintana Roo Speleological Survey, available at: http:// caves.org/project/qrss/qrss.htm, last access: 23 November 2018.

Queen, M. J. and Melim, L. A.: Biothems: biologically influenced speleothems in caves of the Guadalupe Mountains, New Mexico, USA, in: Caves and Karst of Southeastern New Mexico, New Mexico Geological Society Guidebook, 57th Field Conference, edited by: Raatz, W., Land, L., and Boston, P. J., 167-174, 2006.

Rimstidt, J. D., Balog, A., and Webb, J.: Distribution of trace elements between carbonate minerals and aqueous solutions, Geochim. Cosmochim. Ac., 62, 1851-1863, https://doi.org/10.1016/s0016-7037(98)00125-2, 1998.

Schmitter-Soto, J. J., Comín, F. A., Escibar-Briones, E., HerreraSilveira, J., Alcocer, J., Suárez-Morales, E., Elías-Gutiérrez, M., Díaz-Arce, V., Marín, L. E., and Steinich, B.: Hydrogeochemical and biological characteristics of cenotes in the Yucatan Peninsula (SE Mexico), Hydrobiologia, 467, 215-228, 2002.

Seymour, J. R., Humphreys, W. F., and Mitchell, J. G.: Stratification of the microbial community inhabiting an anchialine sinkhole, Aquat. Microb. Ecol., 50, 11-24, https://doi.org/10.3354/ame01153, 2007.

Smart, P. L., Beddows, P. A., Coke, J., Doerr, S., Smith, S., and Whitaker, F. F.: Perspectives on karst geomorphology, hydrology, and geochemistry - a tribute volume to Derek C Ford and William B White, edited by: Harmon, R. S. and Wicks, C. M., Geological Society of America, Boulder, CO, 2006.

Socki, R. A., Perry, E. C., and Romanek, C. S.: Stable isotope systematics of two cenotes from the northern Yucatan Peninsula, Mexico, Limnol. Oceanogr., 47, 1808-1818, https://doi.org/10.4319/lo.2002.47.6.1808, 2002.

Stinnesbeck, S. R., Frey, E., Avilés Olguín, J., Stinnesbeck, W., Zell, P., Mallison, H., González González, A., Núñez, E. A., Velázquez Morlet, A., Terrazas Mata, A., Benavente Sanvicente, M., Hering, F., and Rojas Sandoval, C.: Xibalbaonyx oviceps, a new megalonychid ground sloth (Folivora, Xenarthra) from the Late Pleistocene of the Yucatán Peninsula, Mexico, and its paleobiogeographic significance, PalZ, 91, 245-271, https://doi.org/10.1007/s12542-017-0349-5, 2017a.

Stinnesbeck, W., Frey, E., Zell, P., Avilés, J., Hering, F., Frank, N., Arps, J., Geenen, A., Gescher, J., Isenbeck-Schröter, M., Ritter, S., Stinnesbeck, S., Núñez, E. A., Dahne, V. F., González, A. G., and Deininger, M.: Hells Bells - unique speleothems from the Yucatán Peninsula, Mexico, generated under highly specific subaquatic conditions, Palaeogeogr. Palaeocl., 489, 209229, https://doi.org/10.1016/j.palaeo.2017.10.012, 2017 b.

Stoessell, R. K., Moore, Y. H., and Coke, J. G.: The Occurrence and Effect of Sulfate Reduction and Sulfide Oxidation on Coastal Limestone Dissolution in Yucatan Cenotes, Ground Water, 31, 566-575, 1993.

Tesoriero, A. and Pankow, J.: Solid solution partitioning of $\mathrm{Sr} 2+$, Ba 2+, and Cd 2+ to calcite, Geochim. Cosmochim. Ac., 60, 1053-1063, 1996.

Torres-Talamente, O., Alcocer, J., Beddows, P. A., Escobar-Briones, E. G., and Lugo, A.: The key role of the chemolimnion in meromictic cenotes of the Yucatan Peninsula, Mexico, Hydrobiologia, 677, 107-127, https://doi.org/10.1007/s10750-011-07469, 2011 
Tredici, S. M., Buccolieri, A., Tanini, L., Manno, D., Alifano, P., Maurizio, S., Buccolieri, A., Tanini, L., Manno, D., and Alifano, P.: Calcite-forming Bacillus licheniformis Thriving on Underwater Speleothems of a Hydrothermal Cave Calcite-forming Bacillus licheniformis Thriving on Underwater Speleothems of a Hydrotermal cave, Geomicrobiol. J., 35, 804 817, https://doi.org/10.1080/01490451.2018.1476626, 2018.

Visscher, P. T. and Stolz, J. F.: Microbial mats as bioreactors?: populations, processes, and products, Palaeogeogr. Palaeocl., 219, 87-100, https://doi.org/10.1016/B978-0-444-52019-7.50009-7, 2005.

Weidie, A. E.: Geology of the Yucatán Plattform, in: Geology and Hydrogeology of the Yucatán and Quartenary Geology of Northeastern Yucatán Peninsula, edited by: Ward, W. C., Weidie, A. E., and Back, W., 1-19, New Orleans Geological Society Publication, 1985.
Weiss, R. F.: Carbon Dioxide in Water and Seawater: The Solubility of a Non-Ideal Gas, Mar. Chem., 2, 203-215, 1974.

Whiticar, M. J.: Carbon and hydrogen isotope systematics of bacterial formation and oxidation of methane, Chem. Geol., 161, 191314, 1999.

Wiesenburg, D. A. and Guinasso, N. L.: Equilibrium solubilities of methane, carbon monoxide, and hydrogen in water and sea water, J. Chem. Eng. Data, 24, 356-360, https://doi.org/10.1021/je60083a006, 1979.

Williams, P. W.: The role of the subcutaneous zone in karst hyrology, J. Hydrol., 61, 45-67, 1983.

Yamamoto, S., Alcauskas, J. B., and Crozier, T. E.: Solubility of methane in distilled water and seawater, J. Chem. Eng. Data, 21, 78-80, https://doi.org/10.1021/je60068a029, 1976. 